\title{
A novel selective VPAC2 agonist peptide- conjugated chitosan modified selenium nanoparticles with enhanced anti-type 2 diabetes synergy effects
}

\author{
This article was published in the following Dove Press journal: \\ International Journal of Nanomedicine \\ 20 March 2017 \\ Number of times this article has been viewed
}

\author{
Shao-Jun Zhao ${ }^{1,2, *}$ \\ De-Hua Wang ${ }^{1,2}$ \\ Yan-Wei Li',2 \\ Lei $\mathrm{Han}^{1,2}$ \\ Xing Xiao ${ }^{1,2}$ \\ Min $\mathrm{Ma}^{3, *}$ \\ David Chi-Cheong Wan ${ }^{4}$ \\ An Hong ${ }^{1,2}$ \\ Yi Ma ${ }^{1,2}$ \\ 'Institute of Biomedicine, Department \\ of Cellular Biology, Jinan University, \\ ${ }^{2}$ National Engineering Research \\ Center of Genetic Medicine, Key \\ Laboratory of Bioengineering \\ Medicine of Guangdong Province, \\ Jinan University, ${ }^{3}$ College of \\ traditional Chinese Medicine, Institute \\ of Integrated Traditional Chinese and \\ Western Medicine, Jinan University, \\ Guangdong, ${ }^{4}$ School of Biomedical \\ Sciences, Faculty of Medicine, The \\ Chinese University of Hong Kong, \\ Shatin, Hong Kong SAR, People's \\ Republic of China
}

*These authors contributed equally to this work

Correspondence: Yi Ma; An Hong Institute of Biomedicine, Department of Cellular Biology, Jinan University, 60 I Huangpu Ave West, Guangzhou 510632, Guangdong, People's Republic of China

Tel +862085221983

Fax +86208522 1983

Email tmayi@jnu.edu.cn;

makesi8866@163.com

\begin{abstract}
A novel neuroendocrine peptide, pituitary adenylate cyclase activating peptide (PACAP), was found to have an important role in carbohydrate or lipid metabolism and was susceptible to dipeptidyl peptidase IV degradation. It can not only mediate glucose-dependent insulin secretion and lower blood glucose by activating VPAC2 receptor, but also raise blood glucose by promoting glucagon production by VPAC1 receptor activation. Therefore, its therapeutic application is restricted by the exceedingly short-acting half-life and the stimulatory function for glycogenolysis. Herein, we generated novel peptide-conjugated selenium nanoparticles (SeNPs; named as SCD), comprising a 32-amino acid PACAP-derived peptide DBAYL that selectively binds to VPAC2, and chitosan-modified SeNPs (SeNPs-CTS, SC) as slow-release carrier. The circulating half-life of SCD is $14.12 \mathrm{~h}$ in mice, which is 168.4and 7.1-fold longer than wild PACAP $(\sim 5 \mathrm{~min})$ and DBAYL $(\sim 1.98 \mathrm{~h})$, respectively. SCD $(10 \mathrm{nmol} / \mathrm{L})$ significantly promotes INS-1 cell proliferation, glucose uptake, insulin secretion, insulin receptor expression and also obviously reduces intracellular reactive oxygen species levels in $\mathrm{H}_{2} \mathrm{O}_{2}$-injured INS-1 cells. Furthermore, the biological effects of SCD are stronger than Exendin-4 (a clinically approved drug through its insulinotropic effect), DBAYL, SeNPs or SC. A single injection of SCD $(20 \mathrm{nmol} / \mathrm{kg})$ into $\mathrm{db} / \mathrm{db}$ mice with type 2 diabetes leads to enhanced insulin secretion and sustained hypoglycemic effect, and the effectiveness and duration of SCD in enhancing insulin secretion and reducing blood glucose levels are much stronger than Exendin-4, SeNPs or SC. In db/db mice, chronic administration of SCD by daily injection for 12 weeks markedly improved glucose and lipid profiles, insulin sensitivity and the structures of pancreatic and adipose tissue. The results indicate that SC can play a role as a carrier for the slow release of bioactive peptides and SCD could be a hopeful therapeutic against type 2 diabetes through the synergy effects of DBAYL and SeNPs.
\end{abstract}

Keywords: pituitary adenylate cyclase activating peptide (PACAP)-derived peptide, nanoselenium, VPAC2 receptor, synergy effect, type 2 diabetes (T2D)

\section{Introduction}

Pituitary adenylate cyclase activating peptide (PACAP) is a new member of the glucagon, secretin and vasoactive intestinal peptide (VIP) family, and its structure is highly conservative in all mammals. ${ }^{1,2}$ PACAP and its receptors are located in the gastrointestinal organs, pancreas, adipose or muscle tissues. Current research indicates that PACAP has a significant role in carbohydrate and lipid metabolism, ${ }^{3-6}$ demonstrating PACAP may be a latent antidiabetic agent. By activating VPAC2, 
glucose-dependent insulin secretion was obviously improved when PACAP was overexpressed in transgenic mice. ${ }^{7-9}$ However, PACAP-knockout mice exhibit hypoinsulinemia. ${ }^{6,10}$ Injection of PACAP increased glucose tolerance and decreased blood glucose levels in high-fat dietfed type 2 diabetes (T2D) model mice and Goto-Kakizaki rats. ${ }^{11}$ But wild PACAP can activate the receptors VPAC1 and VPAC2, and VPAC1-mediated hepatic glucose increase counteracts the increased insulin secretion by VPAC2 activation. Thus, PACAP derivatives as VPAC2-specific agonists can effectively promote glucose-dependent insulin secretion, control circulating glucose and protect islet beta cells without causing glucagon secretion and glycogenolysis, and have been proposed as potential T2D therapeutics. ${ }^{12-14}$

BAY55-9837 is a reported specific VPAC2 agonist constructed through site-directed mutagenesis, and it can increase plasma insulin levels in a dose-dependent manner, but not leading to any hypoglycemia in rats. ${ }^{15,16}$ Nevertheless, its therapeutic application has been hampered by its short half-life ( $\sim 5 \mathrm{~min})$ and limited bioavailability in vivo. ${ }^{17}$ Mainly, dipeptidyl peptidase IV-mediated enzymolysis leads to the H-S lack of BAY55-9837 at the N-terminus, which may cause it cannot activate VPAC2. ${ }^{13}$ Moreover, deamidation occurring in the ninth and 28th amino acid Asn $(\mathrm{N})$ results in destabilization and its small molecular size causes rapid renal clearance.

In recent years, a variety of drug delivery systems or strategies have been studied and explored to address the problem of low bioavailability of peptide drugs, for example, the PEGylation techniques. ${ }^{12,18,19}$ Pan et al explored the coupling of dipeptidyl peptidase IV-resistant VPAC2 analog peptides with 22 or $44 \mathrm{kDa}$ polyethylene glycol (PEG) through specific cysteine moieties to improve the pharmacokinetics of these peptides in vivo. ${ }^{13}$ But the large polymers formed by PEG or other modifications often decrease the biological activity of the peptides or interfere with the biological function of the peptides. Therefore, to maintain the activity and function of the peptide drugs in vivo, appropriate slow-release carriers may be used to liberate the active peptides in order.

Nanocarrier, a kind of nanoscale drug delivery system, may not only help to deliver drugs across the blood-brain barrier, but also possess many advantages such as targeted sustained release, high efficiency and low toxicity. Nanoselenium (SeNP) is a nanosize selenium (Se) particle with high biological activity. ${ }^{20}$ As an essential trace element, Se or selenoproteins are biological antioxidants, which can efficiently inhibit lipid peroxidation by removing excess free radicals. Se can prevent the development of diabetes or cardiovascular diseases through maintaining the normal redox status in organisms..$^{21,22}$ Kumar et al have shown that SeNPs can effectively delay the process of diabetes in rats. ${ }^{23}$ SeNPs serve as slow-release drug carrier to extend the half-life of peptide drug and synergistically enhance the drug efficacy. ${ }^{24,25}$

In order to overcome the lack of therapeutic efficacy of BAY55-9837, we first optimized its amino acid composition by gene recombination technology to obtain a 32-amino acid recombinant peptide DBAYL (MHSDAVFTDQYTRLRKQLAAKKYLQSLKQKRY, molecular weight: 3,916.0 Da). By comparing with BAY55-9837, five mutations (an extra $\mathrm{M}$ was added to the $\mathrm{N}$-terminus, N9Q, V17L, I26L and N28Q) were introduced into DBAYL to enhance the VPAC2 receptor potency and stability in vivo. The halflife of DBAYL in mice was $1.98 \mathrm{~h}, \sim 23.8$-fold more than that of BAY55-9837 due to improved stability. In order to further improve the bioavailability of recombinant peptide DBAYL and reduce the high renal clearance caused by small molecular weight, we constructed stable chitosan-modified SeNP (SeNPs-CTS, SC) as a slow-release carrier to conjugate the recombinant peptide DBAYL through amido bond formation between amido of SC and tyrosine carboxyl in DBAYL. Thus, DBAYL-conjugated, chitosan-modified SeNPs (SeNPs-CTS-DBAYL, SCD) were prepared, and the coupled bioactive peptide, DBAYL, could be gradually released because the amido bond formed by chitosan amido and tyrosine carboxyl was scissile to chymotrypsin and cathepsin D hydrolysis. In vitro, SCD can significantly promote INS-1 cell proliferation, insulin expression and secretion, insulin receptor expression and glucose uptake in INS-1 cells. SCD also significantly reduces the level of reactive oxygen species (ROS) that cause oxidative damage in $\mathrm{H}_{2} \mathrm{O}_{2}$-injured INS-1 cells. The in vivo results indicated that DBAYL may be released slowly from SCD in the circulation due to the carrying ability of SC. SCD potently relieved hyperglycemia and T2D through the synergy effects of the SC carrier possessing both slow-release and therapeutic action and the selective VPAC2 agonist peptide DBAYL.

\section{Materials and methods Preparation and identification of peptide DBAYL-conjugated, chitosan-modified SeNPs, SeNPs-CTS-DBAYL}

According to the bias of Escherichia coli for the codons, $D B A Y L$ gene was designed and synthesized through polymerase chain reaction (PCR) previously described using 
three oligonucleotide primers. ${ }^{26}$ The purified PCR products and plasmid pKYB-MCS (NEB, Ipswich, MA, USA) vector were digested by NdeI and SapI and ligated to yield the expression plasmid pKY-DBAYL. DBAYL gene in plasmid pKY-DBAYL was confirmed by DNA sequencing. The vector pKY-DBAYL was transformed into E. coli ER2566 (NEB), and the fusion proteins were expressed and purified by the optimized procedure previously described. ${ }^{26}$ After chitin beads (NEB) affinity chromatography purification was carried out for the cell lysate, the preparation, purity assay and identification were performed by reverse-phase high-performance liquid chromatography (HPLC) and electrospray ionization mass spectrometry methods as previously described. ${ }^{26,27}$

At room temperature, $100 \mu \mathrm{L}$ chitosan $(\mathrm{CTS}, 0.8 \mathrm{mg} / \mathrm{mL})$ was added to $1 \mathrm{~mL}$ of sodium selenite solution $(5 \mathrm{mM})$ and mixed well by stirring, while $1 \mathrm{~mL}$ ascorbic acid solution (Vitamin C, $20 \mathrm{mM}$ ) was added to the solution. After it was allowed to stand for $30 \mathrm{~min}$ at $4^{\circ} \mathrm{C}$, the mixture was dialyzed overnight $(8 \mathrm{~h})$ at $4^{\circ} \mathrm{C}$, and thus, chitosan-modified SeNPs (SC) were obtained. Two milligrams of DBAYL was dissolved in $1 \mathrm{~mL}$ phosphate-buffered saline (PBS) to obtain DBAYL solution, which was then mixed with the previously prepared SC solution. After the volume of the solution was adjusted to $5 \mathrm{~mL}$, the coupling reaction was carried out using EDC/NHS as a catalyst by stirring for $12 \mathrm{~h}$ at room temperature. Then the solution was dialyzed overnight $(12 \mathrm{~h})$ at $4{ }^{\circ} \mathrm{C}$ and peptide DBAYL-conjugated, chitosan-modified SeNPs, SeNPs-CTS-DBAYL (SCD), were prepared.

The particle size and the surface zeta potential of SCD were measured by the nanoparticle and zeta potential analyzer, respectively. In stability assay, the particle size of SCD was measured continuously for 48 days. Fourier transform infrared spectroscopy was used to determine the absorption peak in the wave number range of $400-4,000 \mathrm{~cm}^{-1}$. The morphology of SCD was observed by transmission electron microscopy after the samples were freeze-dried. Elemental composition assay of SCD was performed by energydispersive X-ray spectrometry.

\section{Determination of entrapment efficiency, drug loading and stability of the prepared SCD}

The ultrafiltration-centrifugation technique was used for measuring the amount of free DBAYL. Briefly, $100 \mu \mathrm{L}$ of SCD coupling reaction solution before dialysis was taken in a $1 \mathrm{~mL} 10 \mathrm{kDa}$ ultrafiltration tube (EMD Millipore, Billerica, MA, USA) and centrifuged at 4,000 rpm for $30 \mathrm{~min}$. The filtrate was collected and the content of DBAYL peptide was determined by HPLC. The entrapment efficiency (EE) was calculated using the following formula: $\mathrm{EE}=([$ total DBAYL quantity-free DBAYL quantity in filtrate]/total DBAYL quantity) $\times 100 \%$. The SCD solution after dialysis was dried by lyophilization, and drug loading (DL) of SCD for DBAYL peptide was calculated using the following formula: DL $=([$ total DBAYL quantity-free DBAYL quantity in filtrate]/SCD mass) $\times 100 \%$. The stability of SCD over 48 days was evaluated with the Zetasizer Nano and its size distribution changes were determined.

\section{Assay of SCD release process in vitro and its half-life in $\mathrm{db} / \mathrm{db}$ mice}

In order to assay peptide release of SCD, SCD $(60 \mu \mathrm{g} / \mathrm{mL})$ was incubated in Roswell Park Memorial Institute 1640 medium ( $\mathrm{pH}$ 7.4) supplemented with $10 \%$ fetal bovine serum at $37^{\circ} \mathrm{C}$ under constant shaking at $200 \mathrm{rpm}$. Sixty microliters of the sample was taken out from Eppendorf tube at appropriate intervals $(0,3,6,12,18,24,30,36,42$ and $48 \mathrm{~h}$ ). The quantity of DBAYL was measured by HPLC method at $280 \mathrm{~nm}$.

Male $\mathrm{db} / \mathrm{db}$ mice with T2D (BKS.Cg-m +/+ Leprdb/J; they were purchased from Model Animal Research Center of Nanjing University, Nanjing, People's Republic of China) were intravenously injected SCD dissolved in sterile normal saline (NS, vehicle of SCD or peptides) at a dose of $1.0 \mathrm{mg} / \mathrm{kg}$ through the tail vein. Orbital blood was collected at each time point before dosing and from 0.5 to $24 \mathrm{~h}$ post dosing, and the concentration of SCD was assayed by LC/MS/MS method described previously. ${ }^{28}$ Then the half-life of SCD in mice was measured with one-compartment elimination model and Win-Nonlin version 5.1 (Pharsight Inc., Mountain View, CA, USA). BAY55-9837, DBAYL and Exendin-4 (Ex-4) were used for control.

\section{Competitive binding assay for SCD to VPAC2 receptor}

SCD was dissolved in $1 \mathrm{~mL}$ PBS (pH 7.4) to a final concentration of $200 \mu \mathrm{M}$, and chymotrypsin was added to the mixture at a final concentration of $1 \mu \mathrm{M}$. SCD was digested for $24 \mathrm{~h}$ by chymotrypsin. Then $20 \mu \mathrm{M}$ chymostatin (chymotrypsin inhibitor; Abcam, Burlingame, CA, USA) was added to terminate the digestion reaction, and DBAYL released from SCD was obtained. Human VPAC2-transfected CHO cells (VPAC2-CHO), [ ${ }^{125}$ I]PACAP38, [ $\left.{ }^{125} \mathrm{I}\right] \mathrm{VIP}$ and Apec-Series $\gamma$-counter (ICN Biomedicals Inc., Costa Mesa, CA, USA) were used to measure the half-maximal inhibitory concentrations $\left(\mathrm{IC}_{50}\right.$ values) of SCD, BAY55-9837, PACAP38 and VIP with the method described previously. ${ }^{29}$ 
Assay of the effect of DBAYL on cyclic adenosine monophosphate accumulation

Human VPAC2, VPAC1 or PAC1-transfected CHO cells (VPAC2-CHO, VPAC1-CHO or PAC1-CHO) were cultured in Dulbecco's Modified Eagle's Medium at $37^{\circ} \mathrm{C}$. DBAYL, PACAP38 and the cyclic adenosine monophosphate (cAMP) enzyme immunoassay kit were used for measuring the cAMP accumulation induced by them, and the half-maximal stimulatory concentrations $\left(\mathrm{EC}_{50}\right.$ values) for the three receptors were determined with the method described previously. ${ }^{29}$

\section{Effect of SCD on the proliferation of INS-I cells}

INS-1 cells were cultured in Roswell Park Memorial Institute 1640 medium supplemented with $10 \%$ fetal bovine serum, $0.11 \mathrm{mg} / \mathrm{mL}$ L-glutamine, sodium pyruvate and $50 \mu \mathrm{M}$ $\beta$-mercaptoethanol at $37^{\circ} \mathrm{C}$ with $5 \% \mathrm{CO}_{2}$. INS-1 cells in logarithmic growth phase were inoculated with $1 \times 10^{4}$ cells/well in a 96-well plate and were treated with different gradient concentrations of SC (using the final concentration of SeNPs as the quantitative index, $0,0.2,2,20,40,50,60,70,80$ and $90 \mu \mathrm{M}$ ) or SCD (using the final concentration of DBAYL as the quantitative index, 0, 2.5, 5, 10 and $20 \mathrm{nM}$ ) for $24 \mathrm{~h}$. The cell survival in different groups was determined with tetrazolium-based colorimetric assay (MTT; Sigma-Aldrich, St Louis, MO, USA). For SCD (10 nM) treatment, the same doses of SeNPs, SC (210 nM, using the final concentration of SeNPs as the quantitative index, SeNPs content is same as that of $10 \mathrm{nM} \mathrm{SCD}$ ), BAY55-9837, Ex-4 and DBAYL $(10 \mathrm{nM})$ were used for controls.

For the receptor VPAC2 blocking experiments, cells were preincubated for $30 \mathrm{~min}$ at $37^{\circ} \mathrm{C}$ with $50 \mathrm{nM}$ of a VPAC2selective inhibitor PG99-465 (it was custom synthesized by GL Biochem, Shanghai, People's Republic of China) prior to $10 \mathrm{nM} \mathrm{SCD}$ treatment.

\section{Effect of SCD on ROS levels in $\mathrm{H}_{2} \mathrm{O}_{2}$-injured INS-I cells}

The oxidative injury INS-1 cell model was established with $\mathrm{H}_{2} \mathrm{O}_{2}$ as described previously. ${ }^{30}$ Briefly, INS- 1 cells were inoculated with $1.5 \times 10^{4} \mathrm{cells} / \mathrm{w}$ well in 96 -well plates and were cultured for $72 \mathrm{~h}$ at $37^{\circ} \mathrm{C}$ with $5 \% \mathrm{CO}_{2} . \mathrm{H}_{2} \mathrm{O}_{2}$ was added to the wells at a final concentration of $400 \mu \mathrm{M}$ and the cells were incubated for $1 \mathrm{~h}$. Then the cells were treated for $24 \mathrm{~h}$ in fresh media containing $10 \mathrm{nM}$ of SCD (using the final concentration of DBAYL as the quantitative index). The cell proliferation rates were determined with MTT. Intracellular ROS levels were determined with fluorometric intracellular ROS kit (Sigma-Aldrich) using the method described previously. ${ }^{31}$ For SCD $(10 \mathrm{nM})$ treatment, the same doses of SeNPs, SC ( $210 \mathrm{nM}$, using the final concentration of SeNPs as the quantitative index), BAY55-9837, Ex-4, DBAYL (10 nM) or the same volume of PBS were used for controls.

For the receptor VPAC2 blocking experiments, cells were preincubated for $30 \mathrm{~min}$ at $37^{\circ} \mathrm{C}$ with $50 \mathrm{nM}$ of a VPAC2-selective inhibitor PG99-465 prior to $10 \mathrm{nM} \mathrm{SCD}$ treatment.

\section{Effect of SCD on the proinsulin mRNA expression and insulin secretion of INS-I cells}

INS-1 cells in logarithmic growth phase were inoculated with $1 \times 10^{6}$ cells/well in six-well plates. The cells were incubated in the culture medium containing gradient concentrations of SCD (using the final concentration of DBAYL as the quantitative index, 0, 2.5, 5, 10 and $20 \mathrm{nM}$ ) for $48 \mathrm{~h}$. Total RNA was extracted using trizol and reverse transcribed into complementary DNA using RevertAid (Thermo Fisher Scientific, Waltham, MA, USA). The primers (forward primer: GTGTGGGGAACGTGGTTTCT; reverse primer: CCA GTGCCAAGGTCTGAAGAT) were used for quantitative real-time PCR, and amplification was performed as follows: $94^{\circ} \mathrm{C}$ for $5 \mathrm{~min} ; 35$ cycles of $94^{\circ} \mathrm{C}$ for $15 \mathrm{~s}$, annealing at $60^{\circ} \mathrm{C}$ for $15 \mathrm{~s}$ and extension at $72^{\circ} \mathrm{C}$ for $15 \mathrm{~s}$; final extension at $72^{\circ} \mathrm{C}$ for $5 \mathrm{~min}$. The effects of SCD on the proinsulin mRNA levels were analyzed. For SCD $(10 \mathrm{nM})$ treatment, the same doses of SeNPs, SC (210 nM), BAY55-9837, Ex-4, DBAYL $(10 \mathrm{nM})$ or the same volume of PBS were used for controls.

INS-1 cells in logarithmic growth phase were inoculated with $1 \times 10^{6}$ cells/well in six-well plates and the cells were cultured for $48 \mathrm{~h}$. After washing twice with PBS and once with sugar-free Krebs-Ringer bicarbonate HEPES (KRBH) buffer, the cells were starved in sugar-free KRBH buffer for $2 \mathrm{~h}$. The sugar-free KRBH buffer was removed and replaced by KRBH buffer supplemented with $16.7 \mathrm{mmol} / \mathrm{L}$ glucose (G-KRBH). The cells were incubated in G-KRBH buffer containing gradient concentrations of SCD (using the final concentration of DBAYL as the quantitative index, 0, 2.5, 5, 10 and $20 \mathrm{nM}$ ) for $1 \mathrm{~h}$ in different experimental groups, and the supernatant in each experimental group was collected for insulin content analysis with rat/mouse insulin enzyme-linked immunosorbent assay kit (EMD Millipore). Insulin secretion of SCD (10 nM)-treated INS-1 cells in KRBH buffer respectively supplemented with $5.5,11$, 16.7 or $25 \mathrm{mmol} / \mathrm{L}$ glucose was also determined. For SCD $(10 \mathrm{nM})$ treatment in $\mathrm{KRBH}$ buffer containing $16.7 \mathrm{mmol} / \mathrm{L}$ 
glucose, the same doses of SeNPs, SC (210 nM), BAY559837, Ex-4, DBAYL (10 nM) or the same volume of PBS were used for controls.

For the receptor VPAC2 blocking experiments, cells were preincubated for $30 \mathrm{~min}$ at $37^{\circ} \mathrm{C}$ with $50 \mathrm{nM}$ of a VPAC2-selective inhibitor PG99-465 prior to $10 \mathrm{nM} \mathrm{SCD}$ treatment.

\section{Effect of SCD on the insulin receptor expression and glucose uptake of INS-I cells}

INS-1 cells in logarithmic growth phase were inoculated with $1 \times 10^{6}$ cells/well in six-well plates and the cells were incubated in the culture medium containing gradient concentrations of SCD (using the final concentration of DBAYL as the quantitative index, 0, 2.5, 5, 10 and $20 \mathrm{nM}$ ) for $48 \mathrm{~h}$ in different experimental groups. The total protein in each experimental group was separated by $12 \%$ SDS-PAGE. Insulin Receptor $\beta$ Mouse mAb (Cell Signaling Technology Inc., Boston, MA, USA) was used to perform the Western blot assay with the method described previously. ${ }^{26}$

INS-1 cells in logarithmic growth phase were inoculated with $1 \times 10^{6}$ cells/well in six-well plates and cultured for $48 \mathrm{~h}$. After washing twice with PBS and once with sugar-free $\mathrm{KRBH}$ buffer, the cells were starved in sugar-free KRBH buffer for $2 \mathrm{~h}$. Then sugar-free KRBH buffer was removed and replaced by KRBH buffer respectively supplemented with $5.5,11,16.7$ or $25 \mathrm{mmol} / \mathrm{L}$ glucose in different experimental groups. The cells were incubated in different glucose $\mathrm{KRBH}$ buffer containing $10 \mathrm{nM}$ of SCD (using the final concentration of DBAYL as the quantitative index) for $20 \mathrm{~min}$, and the supernatant in each experimental group was collected for glucose content analysis with glucose assay kit (Abcam). For SCD $(10 \mathrm{nM})$ treatment in KRBH buffer containing $16.7 \mathrm{mmol} / \mathrm{L}$ glucose, the same doses of SeNPs, $\mathrm{SC}(210 \mathrm{nM})$, BAY55-9837, Ex-4, DBAYL (10 nM) or the same volume of PBS were used for controls. Glucose consumption $=($ the initial glucose content - the measured glucose content).

For the receptor VPAC2 blocking experiments, cells were preincubated for $30 \mathrm{~min}$ at $37^{\circ} \mathrm{C}$ with $50 \mathrm{nM}$ of a VPAC2-selective inhibitor PG99-465 prior to $10 \mathrm{nM} \mathrm{SCD}$ treatment.

\section{Acute pharmacodynamic action of SCD for lowering blood glucose and} promoting insulin secretion in $\mathrm{db} / \mathrm{db}$ mice

Forty-eight male 10 -week-old $\mathrm{db} / \mathrm{db}$ mice with T2D were divided into six groups (eight per group) and the blood glucose levels of mice were detected prior to treatments. SCD (using the final concentration of DBAYL as the quantitative index, $20 \mathrm{nmol} / \mathrm{kg}$ ) diluted in sterile NS was injected intraperitoneally into mice. At $0.5,1,2,3,4,5,6,7,8,9,10$, $11,12,13,14$ and $15 \mathrm{~h}$ after SCD injection, blood glucose levels were determined. The same doses of SC $(42.1 \mu \mathrm{g} / \mathrm{kg}$, SeNPs content is same as that of $20 \mathrm{nmol} / \mathrm{kg} \mathrm{SCD}$ ), Ex-4, DBAYL, BAY55-9837 $(20 \mathrm{nmol} / \mathrm{kg})$ or the same volume of NS acted as controls.

Forty-eight male $\mathrm{db} / \mathrm{db}$ mice and grouping were same as above. Intraperitoneal glucose tolerance tests (IPGTTs) were performed using the same doses of SC $(42.1 \mu \mathrm{g} / \mathrm{kg}$, SeNPs content is same as that of $20 \mathrm{nmol} / \mathrm{kg} \mathrm{SCD}), \mathrm{SCD}$, BAY55-9837, Ex-4, DBAYL (20 nmol/kg, peptides was a quantitative index) or the same volume of NS (blank control) with the method described previously. ${ }^{32}$ Insulin levels at each time point during IPGTTs were measured, and the firstphase (5-15 min) insulin secretion (FPIS) and second-phase (15-120 min) insulin secretion were respectively calculated by the method described previously. ${ }^{32}$

\section{Chronic pharmacodynamic action of SCD on food consumption, body weight, glucose and insulin levels, lipid profile and structure of pancreas, liver and adipose tissue in $\mathrm{db} / \mathrm{db}$ mice}

Forty-eight male, 6-week-old $\mathrm{db} / \mathrm{db}$ mice were divided into six groups (eight per group), and eight male $\mathrm{db} / \mathrm{m}$ mice of the same line (purchased from Model Animal Research Center of Nanjing University) acted as controls. Db/db mice were treated respectively with SCD, BAY55-9837, Ex-4, DBAYL $(20 \mathrm{nmol} / \mathrm{kg}), \mathrm{SC}(42.1 \mu \mathrm{g} / \mathrm{kg})$ or the same volume of NS once a day and treated continuously for 12 weeks. At baseline (before treatment) and 3, 6, 9 and 12 weeks after treatment, food or water consumption, body weight, fast glucose and insulin, whole white fat, free fatty acid, triglyceride, total cholesterol, low-density lipoprotein cholesterol and highdensity lipoprotein cholesterol were determined, and insulin tolerance tests were performed at 12 weeks after treatment with the method described previously. ${ }^{32,33}$ The structures of pancreas and adipose tissue in $\mathrm{db} / \mathrm{db}$ mice and $\mathrm{db} / \mathrm{m}$ mice after 12 weeks of treatment were examined with hematoxylin and eosin stain as described previously. ${ }^{34}$

\section{Statistical analysis}

Results are presented as mean \pm standard error of the mean of at least three independent experiments. Differences between 
groups were assayed by variance analysis with Statistical Package for the Social Sciences (SPSS) version 17.0. Post hoc analysis was used if variance analysis was significant. A value of $P<0.05$ was considered significant statistically.

\section{Ethics statement}

The animal experiments were performed after getting approval from the Laboratory Animal Ethics Committee of JiNan University. Animal welfare and experimental procedures were carried out in accordance with the Guide for the Care and Use of Laboratory Animals (Ministry of Science and Technology of China, 2006) and related ethical regulations of JiNan University.

\section{Results}

\section{Preparation and identification of peptide DBAYL-conjugated, chitosan-modified SeNPs (SCD)}

The DNA fragment encoding 32 amino acids of DBAYL was ligated to the NdeI/SapI-digested plasmid pKYB-MCS to obtain the recombinant plasmid pKY-DBAY. The fusion proteins including chitin-binding domain, intein and DBAYL were expressed by the plasmid pKY-DBAYL transformed into E. coli ER2566. Target peptide, DBAYL, was released by intein cleavage induced by $\beta$-mercaptoethanol and was further purified and prepared by HPLC. About $33.7 \mathrm{mg}$ DBAYL may be gained from $1 \mathrm{~L}$ of bacterial culture, and HPLC assay showed the purity of the prepared DBAYL reached 98\% (Figure 1A). Electrospray ionization mass spectrometry analysis indicated that the molecular weight of the prepared DBAYL was 3,916.0 Da, which corresponded to the theoretically calculated result (Figure 1B).

The stable and homogenous peptide DBAYL-conjugated SeNPs (SCD) were prepared by redox reaction. As shown in Figure $1 \mathrm{C}$ and $\mathrm{D}$, in the absence and presence of DBAYL, the morphologic characteristics as observed by transmission electron microscopy for SC showed obvious changes. SeNPs modified by chitosan were well dispersed, and their average diameter was about $72.6 \mathrm{~nm}$. Compared with SC, the average particle sizes of SCD increased by nearly $78.4 \mathrm{~nm}$ (Figure 1E and $\mathrm{F}$ ) and the surface zeta potential increased to $36.4 \mathrm{mV}$ from $27.3 \mathrm{mV}$ (Figure 1G). Fourier transform infrared spectroscopy assays showed that in the spectrum of SC, the strong absorption band present at $3,425.29 \mathrm{~cm}^{-1}$ is attributed to $\mathrm{N}-\mathrm{H}$ stretching vibration or the contribution of $\mathrm{O}-\mathrm{H}$ torsional stretching vibration. The absorption at $1,383.42 \mathrm{~cm}^{-1}$ is derived from an in-plane bending vibrational mode of $\mathrm{CH}_{3}$. The peak at $1,083.19 \mathrm{~cm}^{-1}$ is assigned to the stretching vibration of $\mathrm{C}-\mathrm{O}-\mathrm{C}$ bonds. The characteristic peaks of SC are in perfect accordance with the results of a previous study. ${ }^{35}$ The peak of DBAYL at $3,302.24 \mathrm{~cm}^{-1}$ is attributed to $\mathrm{O}-\mathrm{H}$ groups. The strong absorption of DBAYL at $1,654.78 \mathrm{~cm}^{-1}$ is attributed to $\mathrm{C}=\mathrm{O}$ stretching of amide I, and the presence of the band at $1,544.68 \mathrm{~cm}^{-1}$ may be due to amide II vibrational mode. An absorption band at $1,246.57 \mathrm{~cm}^{-1}$ is assigned to an amide III vibrational mode absorption band. The peak at $1,402.41 \mathrm{~cm}^{-1}$ may result from COO- stretching of ionized amino acid chains (Figure 1H). The characteristic peaks of SCD resemble those of SC and DBAYL; meanwhile, blue shift was observed for the groups of $\mathrm{O}-\mathrm{H}$ and $\mathrm{COO}-$ in $\mathrm{SCD}$, which are attributed to the conjugation of DBAYL to SCD surface. Furthermore, elemental composition analysis confirmed the presence of a sharp peak of SeNPs (32.28\%), together with a peak from a $\mathrm{C}$ atom (39.31\%), $\mathrm{O}$ atom (17.66\%) and an $\mathrm{N}$ atom (10.75\%) from SCD (Figure 1I), and no other element peaks were detected. These results demonstrated peptide DBAYL was successfully conjugated to SC surface by the condensation of DBAYL tyrosine carboxyl $(-\mathrm{COOH})$ with the amino group $(-\mathrm{NH})$ of SC carrier surface.

As shown in Figure 1J, the average diameter of SCD was about $150 \mathrm{~nm}$. Stability tests showed the particle size of SCD remained unchanged during the first 9 days and then displayed a slight and gradual decrease, which may be caused by the release of DBAYL from SC. SCD remained stable at least for 42 days at $4{ }^{\circ} \mathrm{C}$; after the $42 \mathrm{nd}$ day, aggregation and precipitation began to occur. The high stability of SCD can provide support for its future therapeutic application. The EE and DL of SCD to peptide DBYAL were determined by HPLC, and the results indicated that the EE and DL were $40.6 \% \pm 4.62 \%$ and $65.04 \% \pm 3.95 \%$, respectively, which displayed the high loading rate of SC for DBAYL.

\section{SCD has good slow-release effect in vitro and extended in vivo half-life}

The DBAYL-release rates were assayed with HPLC. Figure 2A shows the release profiles of DBAYL from SC into the culture media. During the first $12 \mathrm{~h}$, the release of DBAYL from SCD is displayed distinctly and was up to $62.6 \%$. Followed by gradual release, the cumulative release rate reached $81.9 \%$ after $48 \mathrm{~h}$, which displayed a good slow-release effect of SCD for DBAYL. The rapid release of DBAYL from SCD during the first $12 \mathrm{~h}$ may provide enough DBAYL to execute its biological functions such as promoting postmeal insulin secretion.

In vivo circulating half-life of SCD was found with LC/MS/MS method. As shown in Figure 2B, the half-life of 


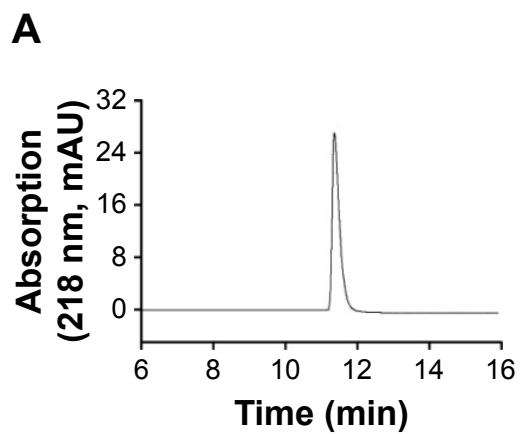

E

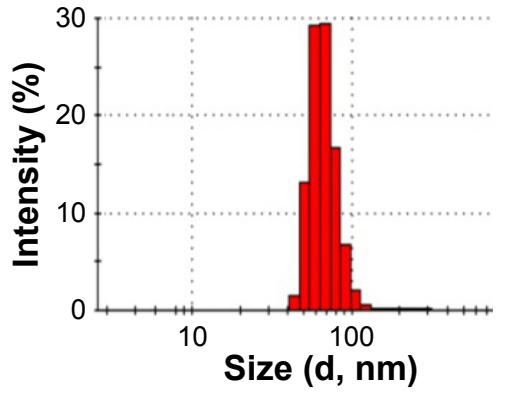

B

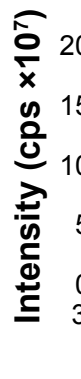

F

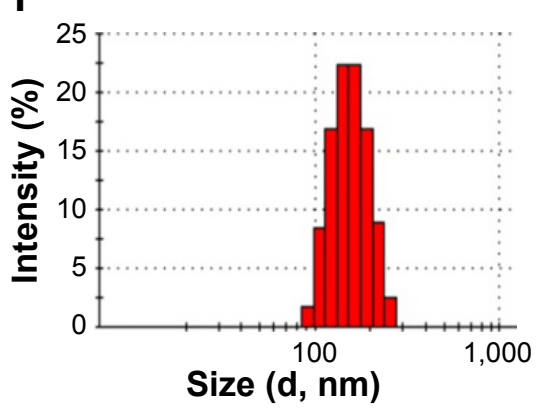

C

D
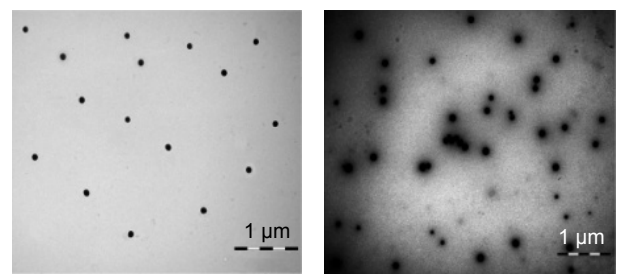

G

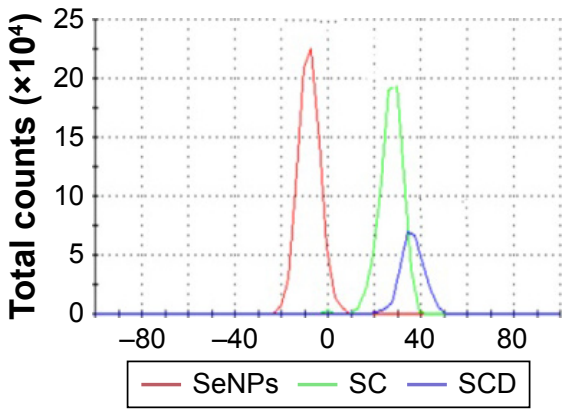

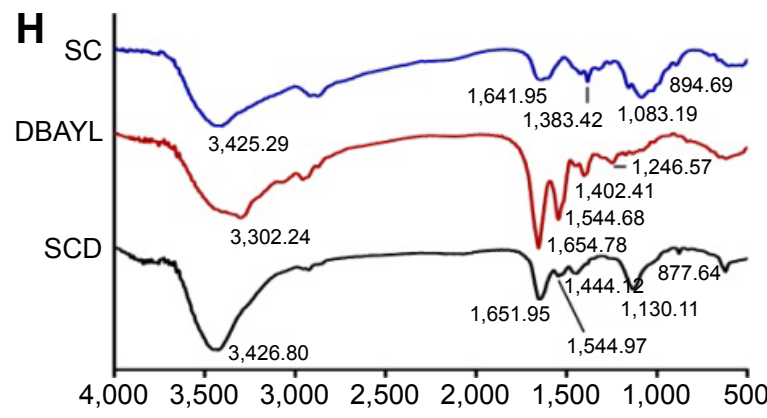
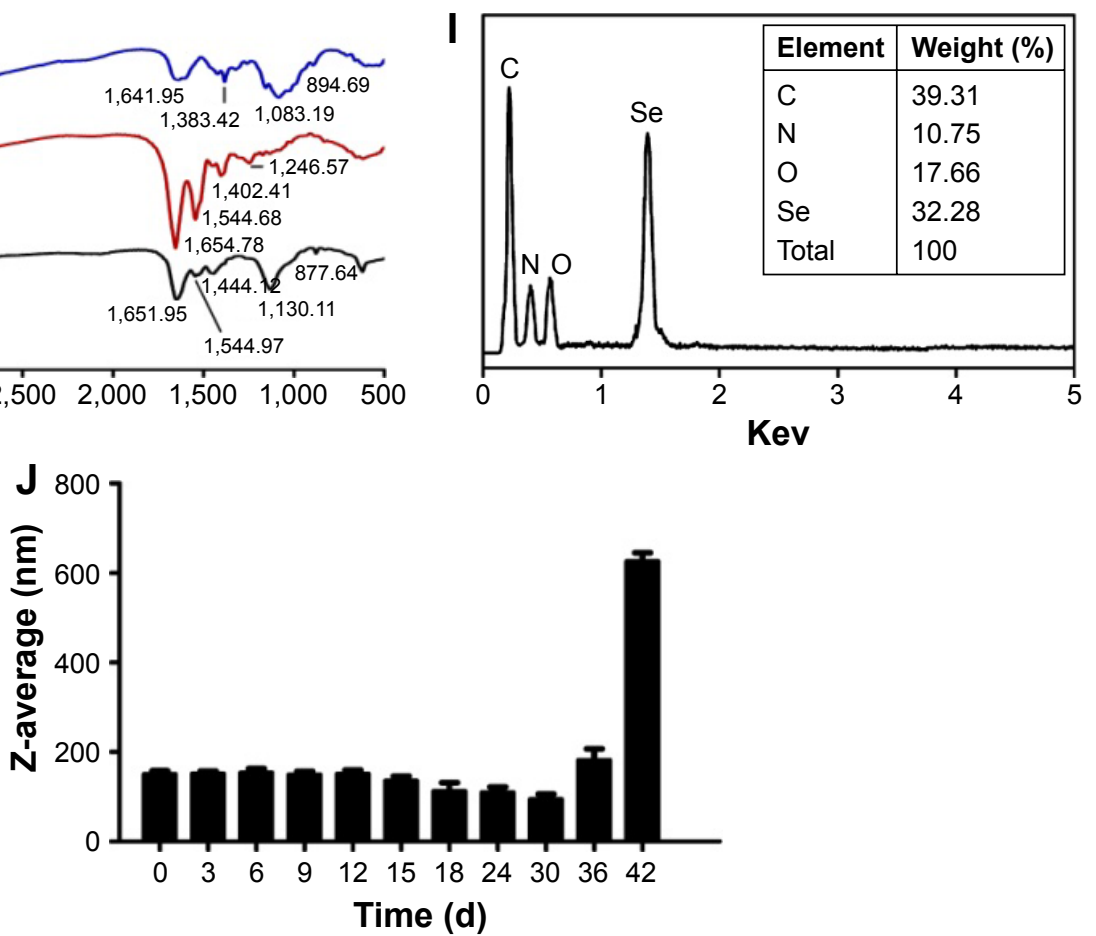

Figure I Identification and analysis of the prepared recombinant DBAYL or SeNPs-CTS-DBAYL (SCD).

Notes: (A) The prepared recombinant DBAYL was analyzed by HPLC. (B) DBAYL was identified by ESI-MS. (C) SeNPs-CTS, SC and (D) SCD were assayed by TEM. Size distribution of (E) SC and (F) SCD. (G) Zeta potential of SeNPs, SC and SCD. (H) FTIR of SC, DBAYL and SCD. (I) EDX spectrometry and (J) stability analysis of SCD. Abbreviations: EDX, Energy dispersive X-ray; ESI-MS, electrospray ionization mass spectrometry; FTIR, Fourier transform infrared spectroscopy; HPLC, high-performance liquid chromatography; SC, chitosan-modified selenium nanoparticles; SCD, DBAYL-conjugated, chitosan-modified selenium nanoparticles; SeNPs, selenium nanoparticles; TEM, transmission electron microscopy.

$\mathrm{SCD}$ in $\mathrm{db} / \mathrm{db}$ mice was $14.12 \mathrm{~h}$, which was about 7.1 -fold higher than unconjugated peptide DBAYL $(1.98 \mathrm{~h})$ and 168.4-fold higher than BAY55-9837. The half-life of SCD was also significantly longer than Ex-4 which has been clinically used, indicating its potential in clinical application.
DBAYL released from SCD may activate specifically and potently VPAC2 receptor

Competition receptor binding assays were performed with VPAC2-CHO cells, [ $\left.{ }^{125} \mathrm{I}\right] \mathrm{PACAP} 38$ and $\left[{ }^{125} \mathrm{I}\right] \mathrm{VIP}$, which helped identify DBAYL as a peptide selectively binding with 

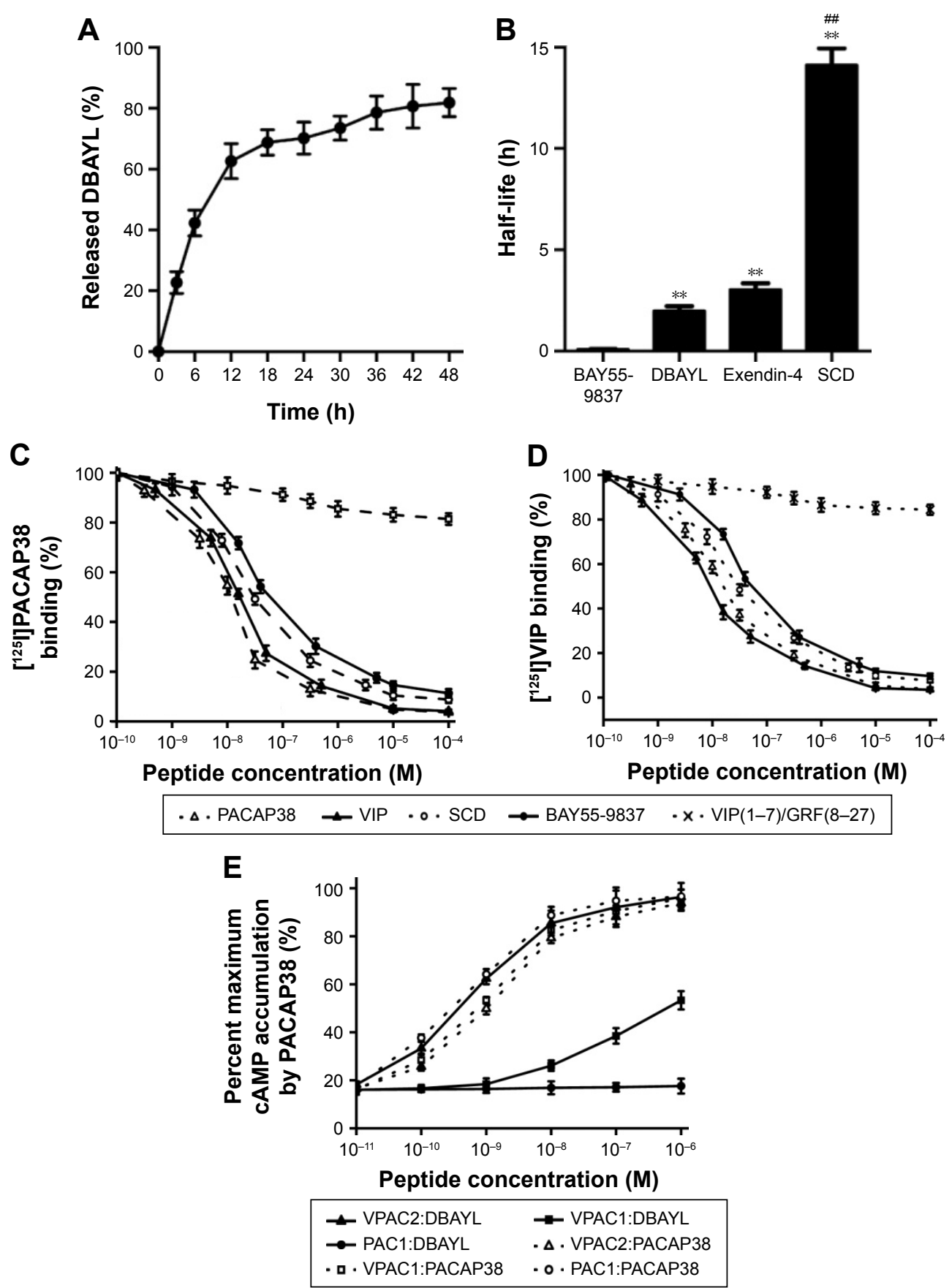

Figure 2 Assay of prepared SCD for in vitro release, in vivo half-life and receptor specificity and potency.

Notes: (A) In vitro release process of DBAYL from SCD in RPMI 1640 cell culture medium supplemented with fetal bovine serum at $37^{\circ} \mathrm{C}$. (B) The half-life of BAY55-9837, DBAYL, Exendin-4 and SCD in db/db mice. Displacement of (C) [ ${ }^{125}$ I]PACAP38 and (D) [ [25]]VIP by SCD, PACAP38, VIP, BAY55-9837 and VIP(I-7)/GRF(8-27) in membranes purified from $\mathrm{CHO}$ cells expressing human VPAC2. (E) cAMP accumulation induced by DBAYL or PACAP38 in CHO-VPAC2, CHO-VPACI and CHO-PACI cells. Results in (C) and (D) are expressed as the percentage of maximum binding to [ ${ }^{125}$ I]PACAP38 or [ ${ }^{125}$ I]VIP. Results in (E) are expressed as the percentage of maximum cAMP accumulation by PACAP38. ${ }^{* * P}<0.01$, SCD, DBAYL or Exendin-4 vs BAY55-9837; $P<0.01$, SCD vs DBAYL or Exendin-4, data are the mean of three independent experiments.

Abbreviations: cAMP, cyclic adenosine monophosphate; PACAP, pituitary adenylate cyclase activating peptide; RPMI, Roswell Park Memorial Institute; SC, chitosanmodified selenium nanoparticles; SCD, DBAYL-conjugated, chitosan-modified selenium nanoparticles; VIP, vasoactive intestinal peptide.

VPAC2. DBAYL may displace $\left.{ }^{[25} \mathrm{I}\right] \mathrm{PACAP} 38$ from VPAC2 competitively with an $\mathrm{IC}_{50}$ of $47.1 \pm 2.2 \mathrm{nM}$, and the $\mathrm{IC}_{50}$ values of BAY55-9837, PACAP38 and VIP were 69.5 \pm 4.3 , $19.3 \pm 2.4$ and $21.2 \pm 1.9 \mathrm{nM}$, respectively (Figure $2 \mathrm{C}$ ). DBAYL displaced [ $\left.{ }^{125} \mathrm{I}\right]$ VIP from VPAC2 competitively with an $\mathrm{IC}_{50}$ of $45.3 \pm 2.7 \mathrm{nM}$ (Figure 2D). The results showed DBAYL released from SCD may selectively bind to VPAC2, and its $\mathrm{IC}_{50}$ of displacing [ $\left.{ }^{125} \mathrm{I}\right] \mathrm{PACAP} 38$ or $\left[{ }^{125} \mathrm{I}\right] \mathrm{VIP}$ competitively was lesser than BAY55-9837.

cAMP accumulation in the three cell lines given above acted as an indicator of agonist potency at the three receptors. DBAYL could potently activate VPAC2 with an $\mathrm{EC}_{50}$ 
of $0.61 \mathrm{nM}$, whereas the $\mathrm{EC}_{50}$ of DBAYL at VPAC1 was $804 \mathrm{nM}$ and DBAYL had no agonist potency for PAC1 (Figure 2E). The $\mathrm{EC}_{50}$ values of PACAP38 for VPAC2, VPAC1 and PAC1 were 1.02, 0.93 and $0.55 \mathrm{nM}$, respectively (Figure 2E). The results indicated PACAP38 may potently activate the three receptors, whereas DBAYL can activate VPAC2 specifically and potently.

\section{SCD at low concentration significantly promotes proliferation of INS-I cells}

INS-1 cells were treated with various concentrations of SC for $24 \mathrm{~h}$, and MTT method was employed to measure the cell proliferation rates. The results showed that SeNPs at a concentration below $40 \mu \mathrm{M}$ (using the final concentration of SeNPs as the quantitative index) had no effects on INS-1 cell proliferation. SC showed dose-dependent inhibitory effects at concentrations $>40 \mu \mathrm{M}$. Also, the $\mathrm{IC}_{50}$ of SC for INS-1 cells was $66.10 \mu \mathrm{M}$, which indicates high concentrations $(>40 \mu \mathrm{M})$ of SeNPs on the INS-1 cells are cytotoxic, but not low concentrations ( $\leq 40 \mu \mathrm{M}$, Figure $3 \mathrm{~A}$ ).

The INS-1 cell proliferation-promoting effects of SCD at low SeNP concentrations (0, 105, 210 and $420 \mathrm{nM})$ were analyzed. As shown in Figure 3B, SCD could promote normal INS-1 cell proliferation below $10 \mathrm{nM}$ (using the
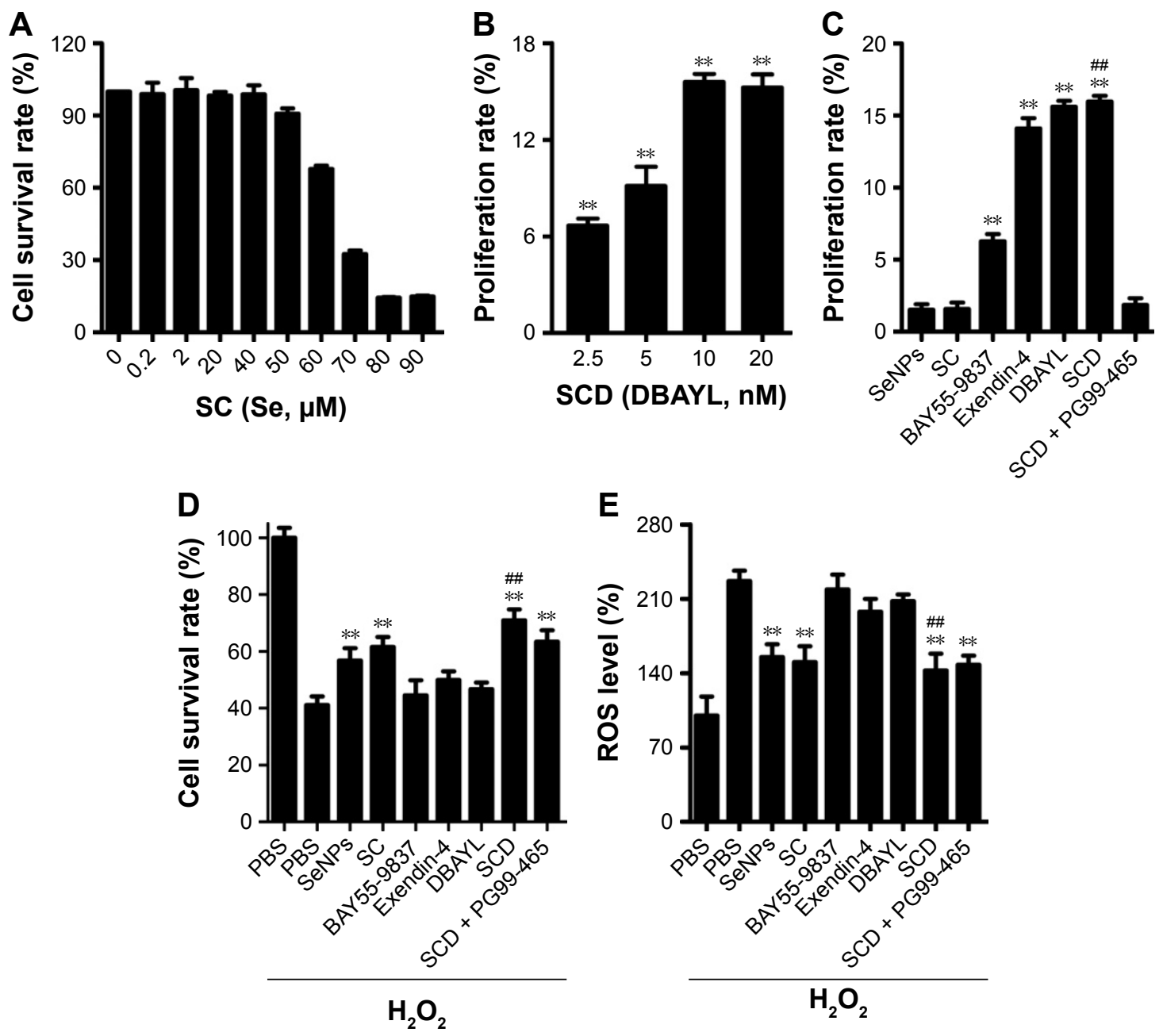

Figure 3 Effects of SCD on normal or $\mathrm{H}_{2} \mathrm{O}_{2}$-injured INS-I cell proliferation and ROS levels in $\mathrm{H}_{2} \mathrm{O}_{2}$-injured INS-I cells.

Notes: (A) The survival of the normal INS-I cells treated with different gradient concentrations of SC (using the final concentration of SeNPs as the quantitative index, $0,10,20,30,40,50,60,70,80$ and $90 \mu \mathrm{M}$ ) was determined by the tetrazolium-based colorimetric assay (MTT assay). (B) Effects of different gradient concentrations of SCD (using the final concentration of DBAYL as the quantitative index, 0, 2.5, 5, 10 and $20 \mathrm{nM}$ ) on normal INS-I cell proliferation. (C) Effects of the same doses of SeNPs, SC (210 nM, using the final concentration of SeNPs as the quantitative index), BAY55-9837, Exendin-4, DBAYL and SCD (I0 nM, using the final concentration of peptides as the quantitative index) on normal INS-I cell proliferation. (D) Effects of the same doses of SeNPs, SC (2I0 nM), BAY55-9837, Exendin-4, DBAYL and SCD (I0 nM) on $\mathrm{H}_{2} \mathrm{O}_{2}$-injured INS-I cell proliferation. (E) Effects of the same doses of SeNPs, SC (2I0 nM), BAY55-9837, Exendin-4, DBAYL and SCD (I0 nM) on the ROS levels in $\mathrm{H}_{2} \mathrm{O}_{2}-$ injured INS-I cells. In the VPAC2 receptor blocking experiments, cells were preincubated with $50 \mathrm{nM}$ of PG99-465 for $30 \mathrm{~min}$ at $37^{\circ} \mathrm{C}$ before adding $10 \mathrm{nM}$ SCD in (C-E). (B) $* * P<0.01$, different gradient concentrations of SCD $(2.5,5,10$ and $20 \mathrm{nM})$ vs blank control (0 nM). (C-E) **P $<0.01$, SeNPs, SC, BAY55-9837, Exendin-4, DBAYL or SCD vs PBS. (C) ${ }^{\# P}<0.0$ I, SCD vs Exendin-4 or BAY55-9837. (D) and (E) ${ }^{\# P<0.01, ~ S C D ~ v s ~ D B A Y L ~ o r ~ E x e n d i n-4 ~(S c h e f f e ́ ~ t e s t, ~} n=3$ ).

Abbreviations: PBS, phosphate-buffered saline; ROS, reactive oxygen species; SC, chitosan-modified selenium nanoparticles; SCD, DBAYL-conjugated, chitosan-modified selenium nanoparticles; SeNPs, selenium nanoparticles. 
final concentration of DBAYL as the quantitative index) in a dose-dependent manner, and the proliferation rate was up to $15.59 \%$ after $10 \mathrm{nM} \mathrm{SCD}$ treatment for $24 \mathrm{~h}$, which was similar to that of DBAYL and obviously higher than that for Ex-4, BAY55-9837, SeNPs and SC (Figure 3C). However, the cell proliferation-promoting effects basically disappeared (similar to that of SC) in INS-1 cells preincubated with $50 \mathrm{nM}$ of the VPAC2-selective inhibitor, PG99-465, for $30 \mathrm{~min}$ prior to $10 \mathrm{nM}$ SCD treatment (Figure 3C). These results indicate that SCD mainly depends on the VPAC2-activation effect of the peptide DBAYL to promote the proliferation of INS-1 cells.

\section{SCD dramatically reduced ROS levels in $\mathrm{H}_{2} \mathrm{O}_{2}$-injured INS-I cells}

ROS level was used as an indicator, and the effect of SCD in protecting INS-1 cells from oxidative damage caused by $\mathrm{H}_{2} \mathrm{O}_{2}$ was explored. INS-1 cells were cultured in the presence of $400 \mu \mathrm{M} \mathrm{H}_{2} \mathrm{O}_{2}$ for $1 \mathrm{~h}$ at $37^{\circ} \mathrm{C}$. After being washed, the cells were treated with $10 \mathrm{nM}$ of SCD in fresh media for $24 \mathrm{~h}$, and the same doses of SC, SeNPs, BAY55-9837, Ex-4, DBAYL or the same volume of PBS were used for positive control or blank control. Cell viability was determined using the MTT assay. As shown in Figure 3D, the addition of $\mathrm{H}_{2} \mathrm{O}_{2}$ significantly decreased INS-1 cell viability, while the cell survival rates were increased by $27.37 \%, 20.41 \%$, $17.89 \%, 3.41 \%, 5.56 \%$ and $8.78 \%$ in SCD-, SC-, SeNPs-, BAY55-9837-, DBAYL- and Ex-4-treated, $\mathrm{H}_{2} \mathrm{O}_{2}$-injured INS-1 cells, compared to PBS-treated, $\mathrm{H}_{2} \mathrm{O}_{2}$-injured INS-1 cell control, respectively. The intracellular ROS levels of each treatment group are shown in Figure 3E. The ROS level was significantly increased in $\mathrm{H}_{2} \mathrm{O}_{2}$-injured INS-1 cells; however, the ROS levels were decreased by $36.84 \%$, $33.11 \%, 31.35 \%, 3.46 \%, 8.34 \%$ and $12.69 \%$ in SCD-, SC-, SeNPs-, BAY55-9837-, DBAYL- and Ex-4-treated, $\mathrm{H}_{2} \mathrm{O}_{2}-$ injured INS-1 cells, respectively, compared to PBS-treated, $\mathrm{H}_{2} \mathrm{O}_{2}$-injured INS-1 cell control. In contrast, the effects of SCD on promoting survival and decreasing ROS were reduced in INS-1 cells preincubated with 50 nM of PG99465 for $30 \mathrm{~min}$ prior to $10 \mathrm{nM} \mathrm{SCD}$ treatment. The cell survival rates and ROS levels in (SCD + PG99-465)-treated, $\mathrm{H}_{2} \mathrm{O}_{2}$-injured INS-1 cells were similar to those of SC-treated groups (Figure 3D and E). These results showed that SCD could obviously increase the survival rates of $\mathrm{H}_{2} \mathrm{O}_{2}$-injured INS-1 cells by eliminating intracellular ROS, and the biological effect was significantly stronger than that of DBAYL or Ex-4. In $\mathrm{H}_{2} \mathrm{O}_{2}$-injured INS-1 cells, the oxidative damage could be effectively inhibited by SCD eliminating
ROS, which mainly depends on the antioxygenation effect of SeNPs or SC.

\section{SCD significantly enhances insulin expression and secretion in INS-I cells}

To detect the effect of SCD on the insulin expression in INS-1 cells, quantitative PCR was used to measure proinsulin mRNA expression levels in INS-1 cells treated with SCD, SC, SeNPs, BAY55-9837, DBAYL, Ex-4 and PBS for $24 \mathrm{~h}$, respectively. The results showed that SCD can increase proinsulin mRNA levels $<10 \mathrm{nM}$ in a dosedependent manner (Figure 4A). The proinsulin mRNA level in $10 \mathrm{nM}$ SCD-treated INS-1 cells was 2.14-fold higher than PBS group. SCD was more potent in promoting proinsulin mRNA expression than DBAYL, Ex-4, BAY55-9837, SC and SeNPs, while SC and SeNPs had no obvious effect on proinsulin mRNA expression (Figure 4B).

Enzyme-linked immunosorbent assay was used to determine the effects of SCD on INS-1 cell insulin secretion. As shown in Figure 4C, SCD possessed potent insulinotropic effect on INS-1 cells in a dose-dependent manner in $\mathrm{KRBH}$ buffer supplemented with $16.7 \mathrm{mmol} / \mathrm{L}$ glucose (Figure 4C). Furthermore, the insulinotropic effects of SCD increased gradually with KRBH buffer glucose concentration increase from 5.5 to $16.7 \mathrm{mM}$ (Figure 4D), and in INS-1 cells treated with $10 \mathrm{nM} \mathrm{SCD}$ in KRBH buffer containing $16.7 \mathrm{mM}$ glucose, the secreted insulin level was about 2.23-fold as compared with that of glucose stimulation alone, which reached $45.97 \mathrm{nIU} / \mathrm{mL} / \mathrm{h}$ (Figure 4E). Ex-4 and BAY55-9837 could also effectively promote insulin secretion in INS-1 cells, but their insulinotropic effects were obviously weaker than that of SCD or DBAYL, while SC or SeNPs only possessed slight insulinotropic effects in INS-1 cells (Figure 4E). In the VPAC2 receptor blocking experiments, SCD promoting proinsulin mRNA expression and insulinotropic effects largely disappeared, and the effects were similar to that of SC (Figure 4B and E). In addition, the insulinotropic effect of SCD in INS-1 cells was stronger than that of DBAYL or SC carrier, indicating that DBAYL and SC in SCD could synergistically promote the insulin secretion of INS-1 cells.

\section{SCD potently promotes insulin receptor expression and glucose uptake in INS-I cells}

INS-1 cells were treated with $0,2.5,5,10$ or $20 \mathrm{nM} \mathrm{SCD}$, respectively, for $48 \mathrm{~h}$, and the expression of insulin receptor $\beta$ subunit was determined by Western blot test. The results showed that SCD can increase insulin receptor 

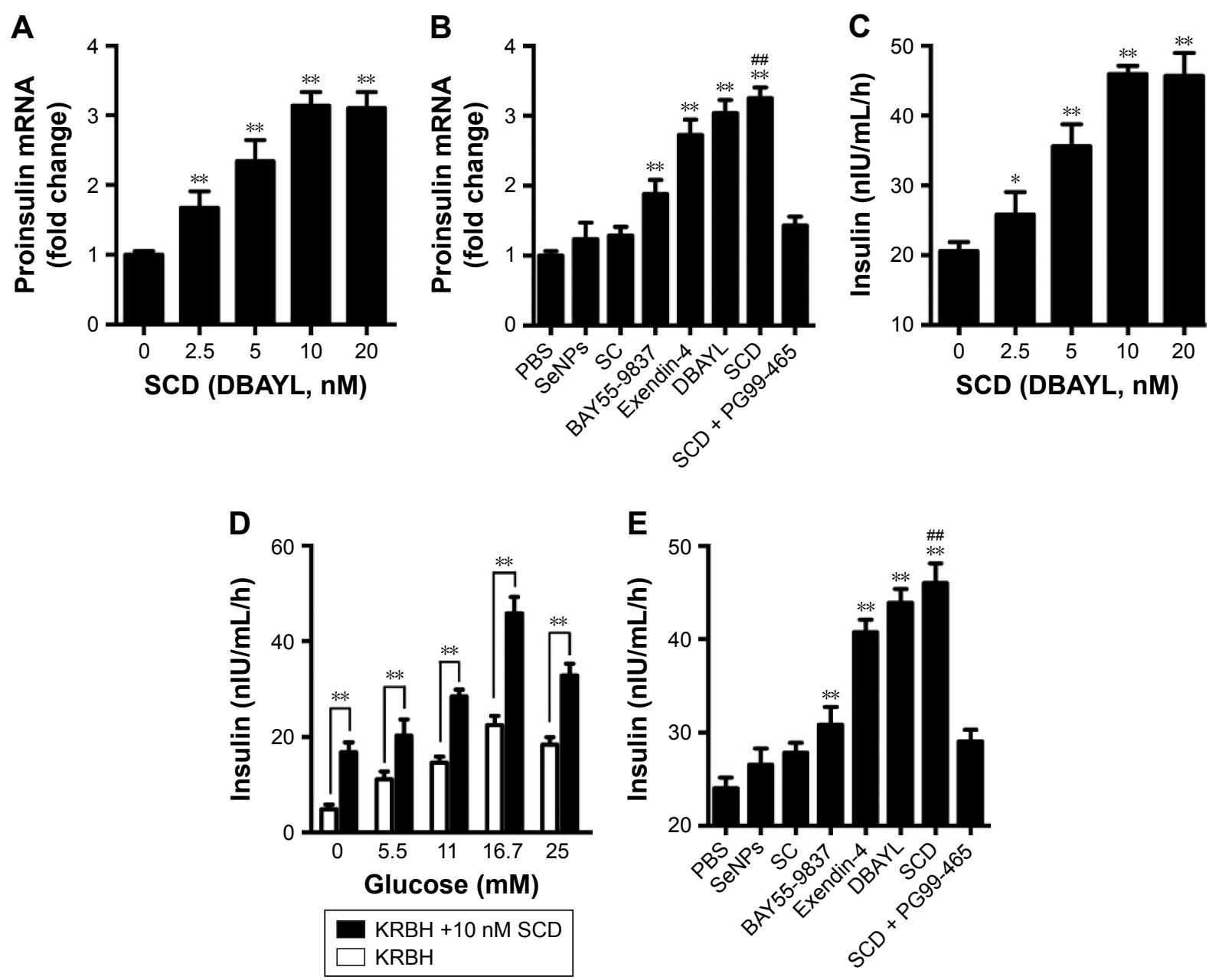

Figure 4 Effects of SCD on the proinsulin mRNA expression and insulin secretion of INS-I cells.

Notes: (A) SCD may significantly promote proinsulin mRNA expression. (B) Effects of the same doses of SeNPs, SC (210 nM), BAY55-9837, Exendin-4, DBAYL and SCD $(I 0 \mathrm{nM})$ on proinsulin mRNA expression. (C) SCD may significantly promote insulin secretion of INS-I cells. (D) Insulin secretion of INS-I cells treated with SCD (I0 nM) in $\mathrm{KRBH}$ buffer supplemented with 5.5, II, 16.7 or $25 \mathrm{mmol} / \mathrm{L}$ glucose, respectively, was determined by ELISA method. (E) Effects of the same doses of SeNPs, SC ( 2 I $0 \mathrm{nM}$ ), BAY55-9837, Exendin-4, DBAYL and SCD (I0 nM) on insulin secretion of INS-I cells treated with SCD (I0 nM) in KRBH buffer supplemented with I6.7 mmol/L glucose. In the VPAC2 receptor blocking experiments, cells were preincubated with $50 \mathrm{nM}$ of PG99-465 for 30 min at $37^{\circ} \mathrm{C}$ before adding $10 \mathrm{nM} \mathrm{SCD}$ in $\mathbf{B}$ and $\mathbf{E}$. (A) and (C) $* P<0.05, * * P<0.0$ I, different gradient concentrations of SCD $(2.5,5,10$ and $20 \mathrm{nM})$ vs blank control $(0 \mathrm{nM})$. (D) $* * P<0.0 \mathrm{I}$, glucose $+10 \mathrm{nM}$ SCD vs glucose. (B) and (E) $* * P<0.0$ I, SeNPs, SC, BAY55-9837, Exendin-4, DBAYL or SCD vs PBS; ${ }^{\# P<0.01, ~ S C D ~ v s ~ B A Y 55-9837, ~ D B A Y L ~ o r ~ E x e n d i n-4 ~(S c h e f f e ́ ~ t e s t, ~} n=3$ ).

Abbreviations: ELISA, enzyme-linked immunosorbent assay; KRBH, Krebs-Ringer bicarbonate HEPES; mRNA, messenger RNA; PBS, phosphate-buffered saline; SC, chitosan-modified selenium nanoparticles; SCD, DBAYL-conjugated, chitosan-modified selenium nanoparticles; SeNPs, selenium nanoparticles.

expression at a concentration $<10 \mathrm{nM}$ in a dose-dependent manner (Figure 5A and B). In $10 \mathrm{nM}$ SCD-treated INS-1 cells, the insulin receptor expression level was 1.72-fold that of PBS group, which was significantly higher than that of Ex-4 (1.35-fold), DBAYL (1.56-fold), BAY559837 (1.25-fold), SeNPs (1.17-fold) and SC (1.18-fold; Figure 5C and D). But promotion of insulin receptor expression effects largely reduced in INS-1 cells preincubated with $50 \mathrm{nM}$ of PG99-465 prior to $10 \mathrm{nM}$ SCD treatment. The results showed that SCD could potently promote the insulin receptor expression in INS-1 cells, and the biological effect is stronger than DBAYL, SC or Ex-4 due to the synergy effects of DBAYL and SC.
The effect of $10 \mathrm{nM}$ SCD on INS-1 cells' glucose uptake from the culture buffer was determined, and the same doses of SeNPs, SC, BAY55-9837, Ex-4, DBAYL or PBS were used for controls. As shown in Figure 5E, compared with glucose stimulation alone and PBS, 10 nM SCD could significantly enhance the glucose uptake of INS-1 cells from the culture buffer containing 5.5, 11.0, 16.7 or $25.0 \mathrm{mM}$ glucose in varying degrees, respectively. The glucose uptake of INS-1 cells cultured in KRBH buffer containing $16.7 \mathrm{mM}$ glucose was the highest and 1.95-fold that of glucose alone, and reached $2.31 \mathrm{mM}$ (Figure 5F), which was higher than that of Ex-4 (1.81 mM), DBAYL (2.06 mM), BAY55-9837 (1.44 mM), SeNPs (1.05 mM) and SC (1.06 mM). However, 


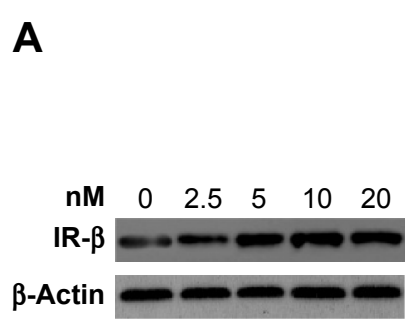

C

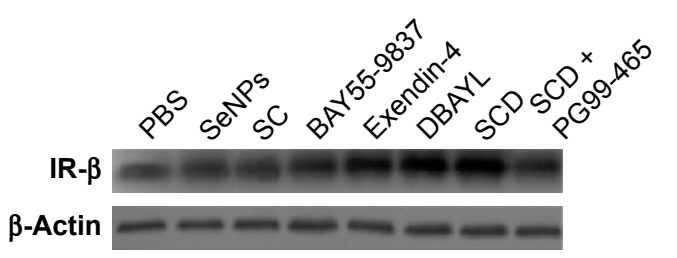

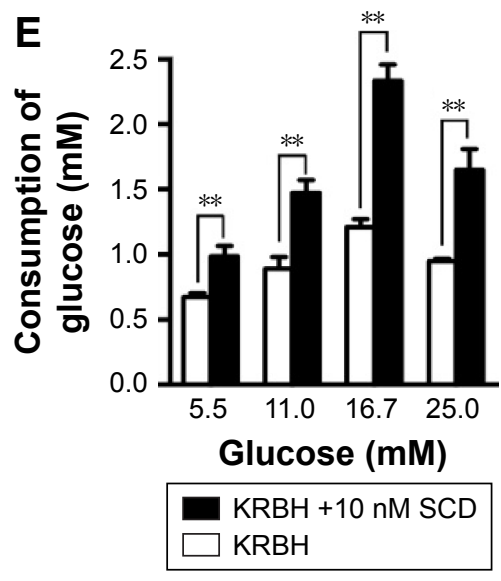

B

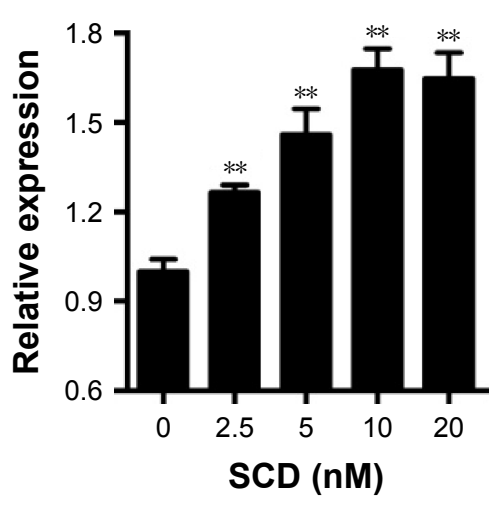

D

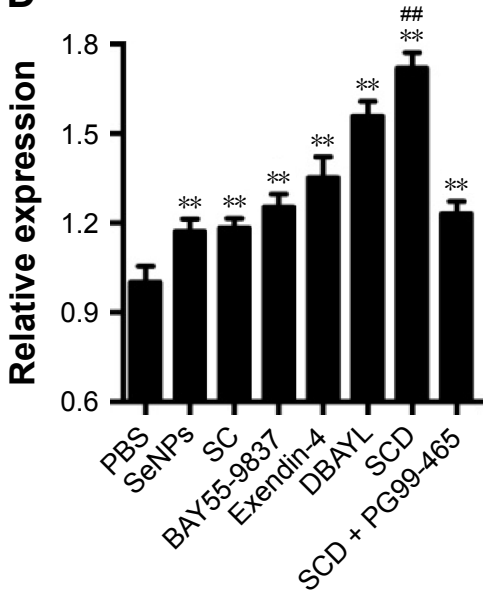

$\mathbf{F}$

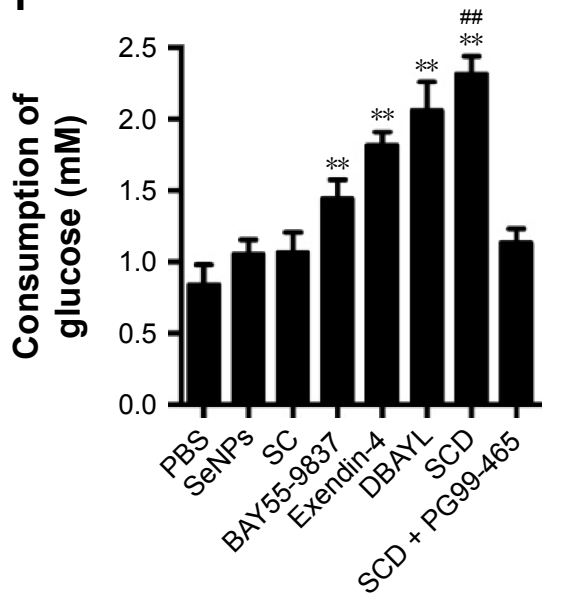

Figure 5 SCD significantly promoted insulin receptor expression and glucose uptake of INS-I cells.

Notes: (A) Effects of different gradient concentrations of SCD on IR- $\beta$ expression. (B) Relative expression assay for IR- $\beta$ in A. (C) Effects of the same doses of SeNPs, SC $(210$ nM), BAY55-9837, Exendin-4, DBAYL and SCD (I0 nM) on IR- $\beta$ expression. (D) Relative expression assay for IR- $\beta$ in (C). (E) Glucose uptake of INS-I cells treated with SCD $(10 \mathrm{nM})$ in KRBH buffer supplemented with 5.5, II, I6.7 or $25 \mathrm{mmol} / \mathrm{L}$ glucose, respectively. (F) Glucose uptake of INS-I cells treated with the same doses of SeNPs, SC (210 nM), BAY55-9837, Exendin-4, DBAYL and SCD (10 nM) in KRBH buffer supplemented with 16.7 mmol/L glucose. (B) $* * P<0.01$, different gradient concentrations of SCD $(2.5,5,10$ and $20 \mathrm{nM})$ vs blank control $(0 \mathrm{nM})$. (E) $* * \mathrm{P}<0.0 \mathrm{I}$, glucose $+10 \mathrm{nM}$ SCD vs glucose. (D) and (F) $* * P<0.0$ I, SeNPs, SC, BAY55-9837, Exendin-4, DBAYL or SCD vs PBS; ${ }^{\#}<0.01$, SCD vs DBAYL or Exendin-4 (Scheffé test, $n=3$ ).

Abbreviations: IR- $\beta$, insulin receptor $\beta$-subunit; KRBH, Krebs-Ringer bicarbonate HEPES; PBS, phosphate-buffered saline; SC, chitosan-modified selenium nanoparticles; SCD, DBAYL-conjugated, chitosan-modified selenium nanoparticles; SeNPs, selenium nanoparticles.

in the VPAC2 receptor blocking experiments, the effects of SCD in promoting glucose uptake largely disappeared (similar to that of SC). Thus, these results indicate that SCD can promote the glucose uptake of INS-1 cells more effectively by the synergy effects of DBAYL and SC.

\section{A single intraperitoneal dosing of SCD for $\mathrm{db} / \mathrm{db}$ mice effectively promotes insulin secretion and lowers blood glucose}

In order to determine the acute pharmacodynamic action of SCD, 10-week-old db/db mice were treated with SCD, Ex-4, BAY55-5837 and NS, respectively, by a single intraperitoneal dosing. The results showed that SCD could lower the blood glucose levels in a dose-dependent manner, and its hypoglycemic effect was found as early as $30 \mathrm{~min}$ postdosing. Furthermore, the hypoglycemic activity significantly lasted for at least $13 \mathrm{~h}$. Glucose levels were $52.1 \%$ and $78.4 \%$, respectively, lesser than the baseline glucose levels at $30 \mathrm{~min}$ and $13 \mathrm{~h}$ postdosing in $20 \mathrm{nmol} / \mathrm{kg} \mathrm{SCD}$-treated $\mathrm{db} / \mathrm{db}$ mice (Figure 6A). The hypoglycemic effect of Ex-4 was nearly the same as that of SCD within $30 \mathrm{~min}$, whereas the effects of Ex-4 at 6 and $13 \mathrm{~h}$ postdosing were significantly lesser than SCD. BAY55-5837 only had momentary hypoglycemic effect within $30 \mathrm{~min}$ (Figure 6A).

IPGTTs and insulin levels at different time points in IPGTTs were used to determine the effects of SCD on glucose tolerance and insulin secretion. $\mathrm{Db} / \mathrm{db}$ mice were injected intraperitoneally with $\mathrm{SC}(42.1 \mu \mathrm{g} / \mathrm{kg}), \mathrm{SCD}$, 
A

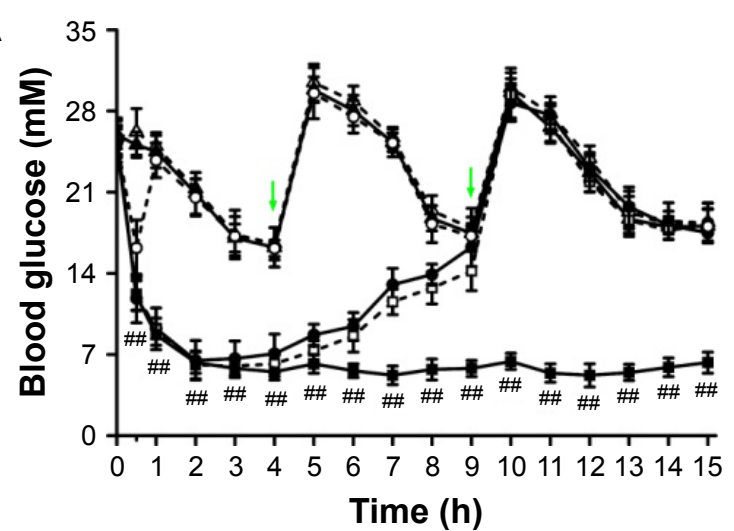

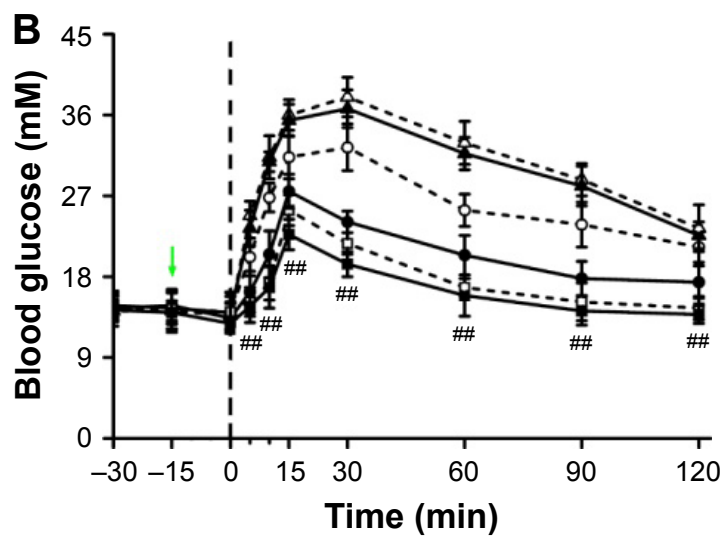

Time (min)

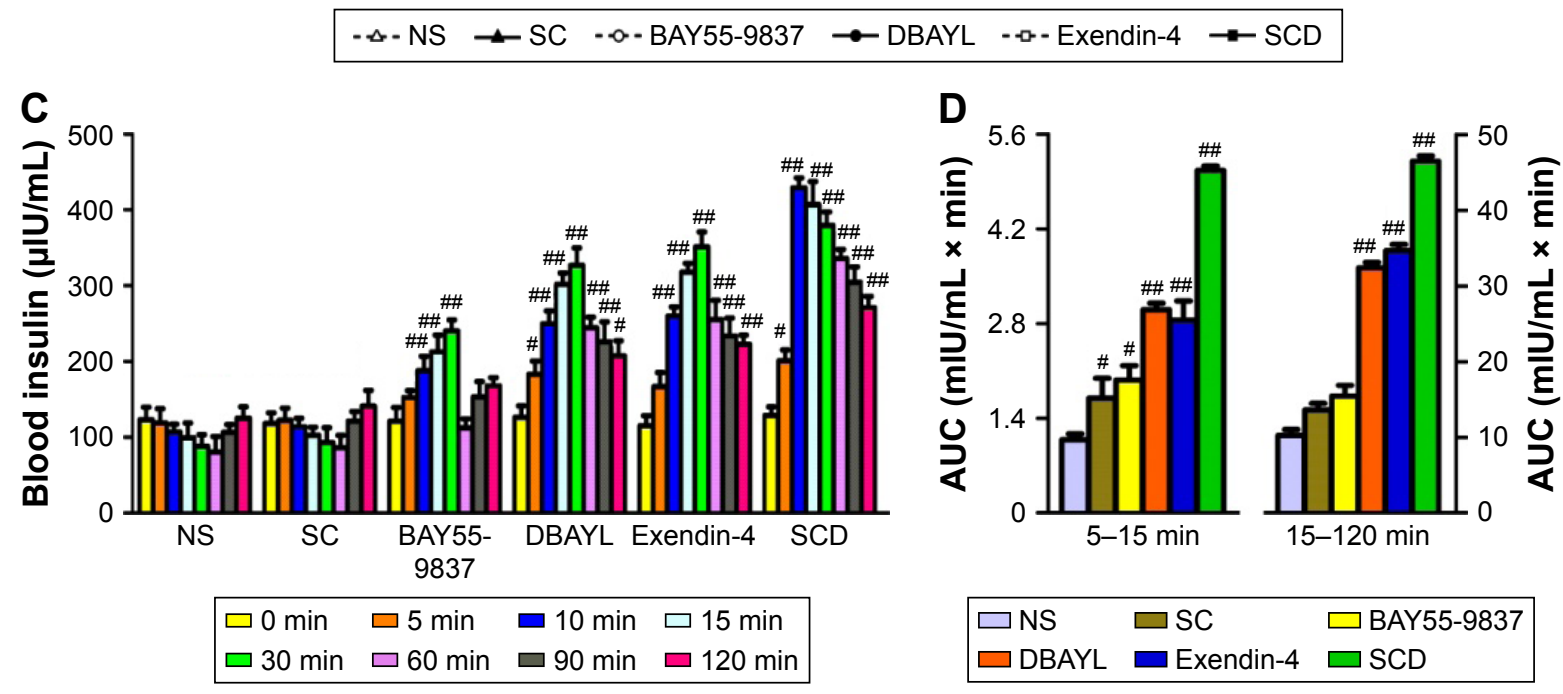

Figure 6 Acute effect of SCD on hyperglycemia, glucose tolerance, first-phase (5-15 min) and second-phase ( $15-120 \mathrm{~min})$ insulin secretion in db/db mice.

Notes: (A) The effect of SCD on blood glucose in 10 -week-old male $\mathrm{db} / \mathrm{db}$ mice. Food was removed I $\mathrm{h}$ before the experiment (-60 min). After the plasma samples were collected (time 0), SCD, Exendin-4, BAY55-9837 (20 nmol/kg) or NS was immediately intraperitoneally injected into the db/db mice. Glucose levels in $\mathrm{db} / \mathrm{db}$ mice were measured at I-I5 h after administration. The mice were regularly fed (marked by arrows). (B) Intraperitoneal glucose tolerance tests in I0-week-old male db/db mice. (C) Insulin levels in IPGTT. (D) AUC for the first phase (5-15 min) and second phase (I5-120 min) of insulin secretion during IPGTT. Data are the mean of eight independent experiments. Data presented as mean \pm SEM. ${ }^{\# P}<0.05$, SCD-treated mice vs BAY55-9837- or NS-treated mice, BAY55-9837- or SC-treated mice vs NS-treated mice; $\ldots P<0$.0I, SCD-, Exendin-4-, DBAYL- or BAY55-9837-treated mice vs NS-treated mice, SCD-treated mice vs BAY55-9837- or NS-treated mice.

Abbreviations: AUC, area under the curve; IPGTT, intraperitoneal glucose tolerance test; NS, normal saline; SC, chitosan-modified selenium nanoparticles; SCD, DBAYLconjugated, chitosan-modified selenium nanoparticles; SEM, standard error of the mean; SeNPs, selenium nanoparticles.

BAY55-9837, Ex-4, DBAYL (20 nmol/ $\mathrm{kg})$ or the same volume of NS at 15 min prior to a glucose challenge, and the blood glucose and insulin levels at different time points were measured. The results indicated NS-treated $\mathrm{db} / \mathrm{db}$ mice displayed significant glucose intolerance and obvious FPIS (5-15 min) deficiency, whereas glucose tolerance was markedly improved in SCD-treated $\mathrm{db} / \mathrm{db}$ mice, as characterized by rapid decrease in blood glucose and significantly lesser area under the curve, compared to other treatments (Figure 6B and C). Furthermore, SCD-treated $\mathrm{db} / \mathrm{db}$ mice exhibited obvious glucose-stimulated insulin secretion restoration. The area under the curve for glucose-stimulated FPIS was 3.69-fold higher than NS, while there was only a 0.57 -, 1.78-, 1.64- and 0.82-fold increase in glucose-stimulated FPIS in SC-, DBAYL-, Ex-4- and BAY55-9837-treated mice, respectively (Figure 6D). Glucose-stimulated second-phase insulin secretion (15-120 min) in SC-, DBAYL-, Ex-4-, BAY55-9837- and SCD-treated mice was 0.33-, 2.17-, 2.39-, 0.51- and 3.55-fold, respectively, higher than NS (Figure 6D). Consistent with these results, SC-, DBAYL-, Ex-4- and BAY55-9837-mediated alleviation of glucose intolerance was obviously weaker than SCD.

\section{Chronic administration of SCD effectively improves fasting glucose levels, insulin resistance, lipid profiles and related tissue structures in $\mathrm{db} / \mathrm{db}$ mice}

For exploring the chronic pharmacodynamic action of SCD, 6-week-old $\mathrm{db} / \mathrm{db}$ mice were injected intraperitoneally once 
A

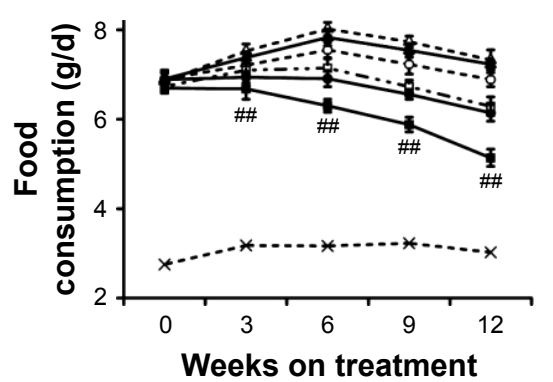

B

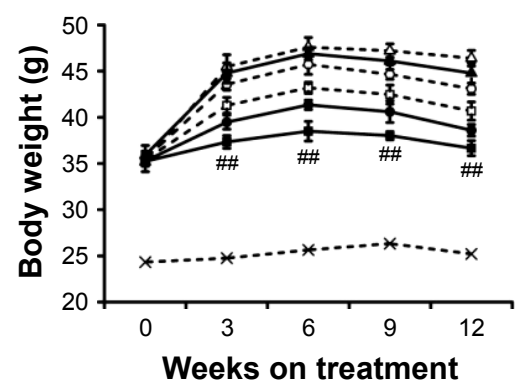

C

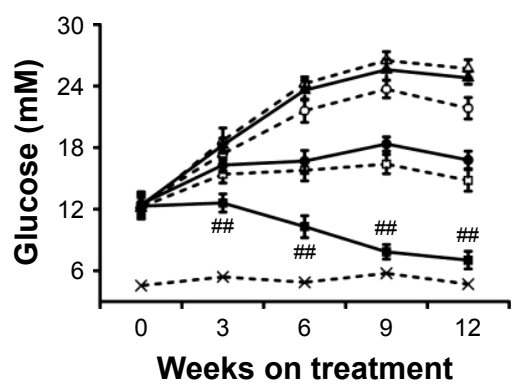

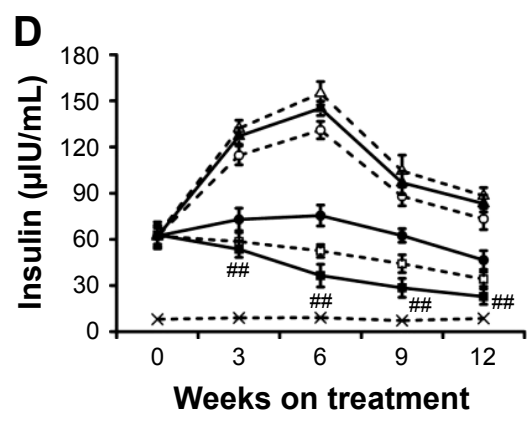

E

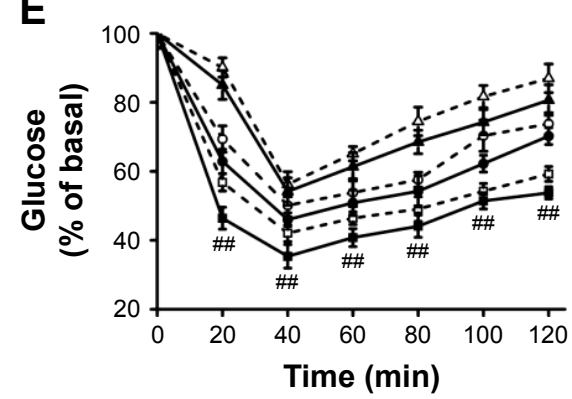

$-\Delta-\mathrm{NS} \rightarrow \mathrm{SC} \quad-0-\mathrm{BAY} 55-9837 \rightarrow \mathrm{DBAYL} \quad-\mathrm{a}-$ Exendin-4 $\rightarrow \mathrm{SCD} \quad-\not-\mathrm{db} / \mathrm{m}$

Figure 7 Effect of chronic administration of SCD on $\mathrm{db} / \mathrm{db}$ mice treated for 12 weeks.

Notes: Effect of SC $(42.1 \mu \mathrm{g} / \mathrm{kg}$, SeNPs content is same to that of $20 \mathrm{nmol} / \mathrm{kg} \mathrm{SCD})$, SCD, Exendin-4, BAY55-9837 (20 nmol/kg, using the final concentration of peptides as the quantitative index) or the same volume of NS on (A) food intake, (B) body weight, (C) fasting glucose, (D) fasting insulin levels during I2-week treatment and (E) ITT of $\mathrm{db} / \mathrm{db}$ mice after I2-week treatment. Data are the mean of eight independent experiments. Data presented as mean \pm SEM. ${ }^{\prime} P<0.0$ I, SCD or Exendin-4-treated mice vs BAY55-9837- or NS-treated mice.

Abbreviations: ITT, insulin tolerance test; NS, normal saline; SC, chitosan-modified selenium nanoparticles; SCD, DBAYL-conjugated, chitosan-modified selenium nanoparticles; SEM, standard error of the mean; SeNPs, selenium nanoparticles.

per day with SC (42.1 $\mu \mathrm{g} / \mathrm{kg})$, DBAYL, Ex-4, BAY55-9837 or $\operatorname{SCD}(20 \mathrm{nmol} / \mathrm{kg})$ or the same volume of NS for a period of 12 weeks. In SCD-treated db/db mice, food or water consumption, body weight and whole white fat were obviously decreased (Figure 7A and B; Table 1). As shown in Figure $7 \mathrm{C}$ and $\mathrm{D}$, NS-treated $\mathrm{db} / \mathrm{db}$ mice exhibited a gradual development of fasting hyperinsulinemia and hyperglycemia, whereas fasting insulin and glucose were markedly decreased in SCD-treated $\mathrm{db} / \mathrm{db}$ mice. Especially, insulin tolerance tests showed SCD-treated $\mathrm{db} / \mathrm{db}$ mice had obviously higher insulin sensitivity (Figure 7E). Compared with SC-, BAY55-9837or NS-treated $\mathrm{db} / \mathrm{db}$ mice, the lipid profiles were significantly improved, as characterized by reduced levels of free fatty acids, triglyceride, total cholesterol and low-density lipoprotein cholesterol in SCD-treated $\mathrm{db} / \mathrm{db}$ mice, and the chronic pharmacodynamic benefits of SCD were much stronger than

Table I The effect of SCD on lipid profile and physiologic parameters of 6-week-old db/db mice that were treated by daily intraperitoneal injection for a period of 12 weeks

\begin{tabular}{|c|c|c|c|c|c|c|c|}
\hline \multirow[t]{2}{*}{ Parameters } & \multirow[t]{2}{*}{$\mathrm{db} / \mathrm{m}$} & \multicolumn{6}{|l|}{$\mathrm{db} / \mathrm{db}+$} \\
\hline & & NS & SC & BAY55-9837 & DBAYL & Exendin-4 & SCD \\
\hline $\mathrm{CHOL}(\mathrm{mmol} / \mathrm{L})$ & $1.84 \pm 0.15$ & $2.53 \pm 0.26 * *$ & $2.39 \pm 0.17^{* *}$ & $2.55 \pm 0.25 * *$ & $2.15 \pm 0.22^{\#}$ & $2.48 \pm 0.21$ & $1.94 \pm 0.13^{\#}$ \\
\hline $\mathrm{TG}(\mathrm{mmol} / \mathrm{L})$ & $0.86 \pm 0.09$ & $2.18 \pm 0.16 * *$ & $2.02 \pm 0.13^{* *}$ & $1.93 \pm 0.14 * *$ & $1.60 \pm 01 \mathrm{I}$ & $1.33 \pm 0.12^{\ldots}$ & $1.14 \pm 0.08$ \\
\hline LDL-C (mmol/L) & $0.31 \pm 0.03$ & $0.70 \pm 0.08 * *$ & $0.68 \pm 0.04^{* *}$ & $0.63 \pm 0.12^{* *}$ & $0.55 \pm 0.08^{\#}$ & $0.69 \pm 0.06$ & $0.40 \pm 0.04^{\#}$ \\
\hline HDL-C (mmol/L) & $1.23 \pm 0.13$ & $1.41 \pm 0.16 * *$ & $1.43 \pm 0.12^{* *}$ & $1.46 \pm 0.20 * *$ & $1.57 \pm 0.44^{\#}$ & $\mathrm{I} .62 \pm 0.2 \mathrm{I}^{\#}$ & $1.74 \pm 0.16^{\#}$ \\
\hline Water consumption $(\mathrm{g} / \mathrm{d})$ & $5.3 \pm 1.4 \mid$ & $27.1 \pm 1.79 * *$ & $25.9 \pm 1.23 * *$ & $27.2 \pm 1.90^{* *}$ & $16.8 \pm 1.25^{\#}$ & $16.1 \pm 1.25^{\#}$ & $10.6 \pm 1.64$ \\
\hline Free fatty acid (mEq/L) & $0.70 \pm 0.22$ & $1.32 \pm 0.35 * *$ & $\mathrm{I} .34 \pm 0.3 \mathrm{I} * *$ & $1.30 \pm 0.19^{* *}$ & $1.06 \pm 0.29 \ldots$ & $0.84 \pm 0.27^{\# \#}$ & $0.75 \pm 0.26 \#$ \\
\hline Whole white fat (g) & $0.6 \pm 0.09$ & $16.7 \pm 1.95 * *$ & $15.9 \pm 1.72^{* *}$ & $15.3 \pm 1.28 * *$ & $10.6 \pm 1.29 \ldots$ & $10.9 \pm 1.29^{\#}$ & $7.20 \pm 1.09 \#$ \\
\hline
\end{tabular}

Notes: ${ }^{* * P}<0.01$, BAY55-9837-, SC- or NS-treated db/db mice vs normal control db/m mice; ${ }^{\#} P<0.05$, \#P<0.0I, SCD, DBAYL or Exendin-4-treated $\mathrm{db} / \mathrm{db}$ mice vs BAY55-9837-, SC- or NS-treated db/db mice. Data are the mean of eight independent experiments. Data presented as mean \pm SEM.

Abbreviations: CHOL, cholesterol; HDL-C, high-density lipoprotein cholesterol; LDL-C, low-density lipoprotein cholesterol; NS, normal saline; SC, chitosan-modified selenium nanoparticles; SCD, DBAYL-conjugated, chitosan-modified selenium nanoparticles; SEM, standard error of the mean; TG, triglyceride. 


\section{A}
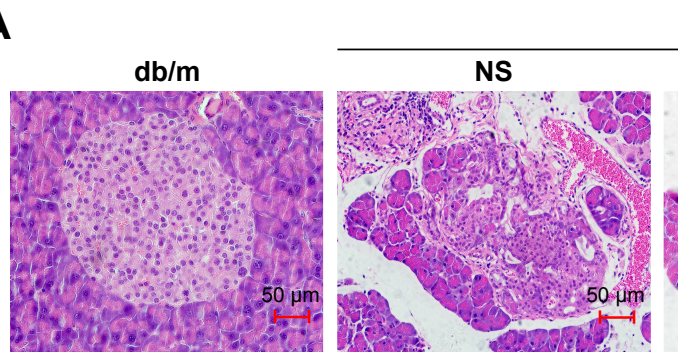

\section{$\mathrm{db} / \mathrm{db}$}

sc

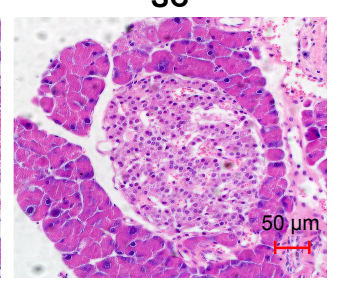

BAY55-9837

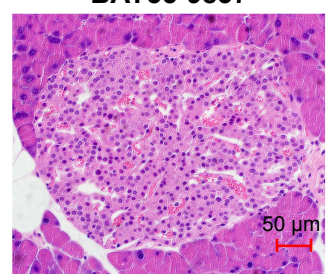

$\mathrm{db} / \mathrm{db}$

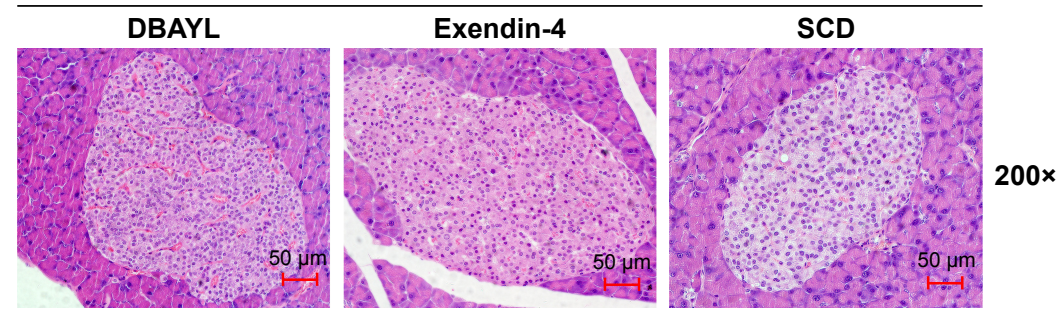

\section{B}

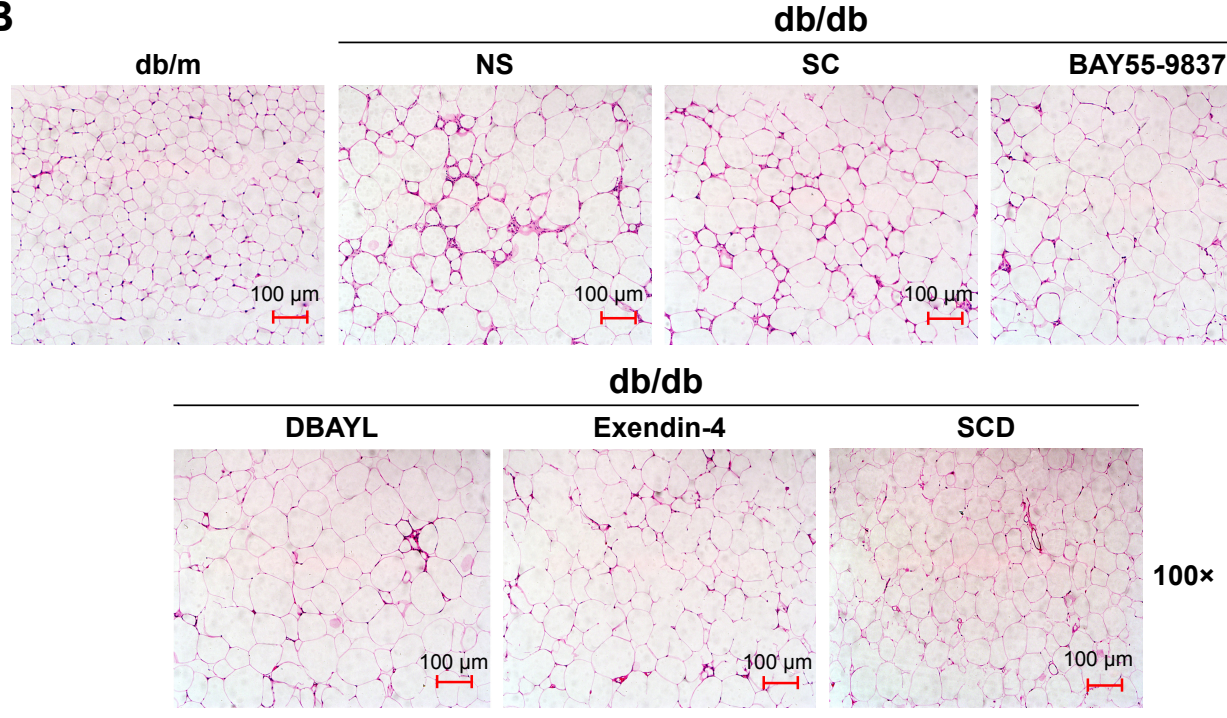

Figure $8 \mathrm{HE}$ staining for determination of pancreas (A) and adipose tissue (B) in 6-week-old male db/m mice and db/db mice respectively treated with SCD, BAY55-9837, Exendin-4, DBAYL $(20 \mathrm{nmol} / \mathrm{kg})$, SC $(42.1 \mu \mathrm{g} / \mathrm{kg})$ or the same volume of NS for 12 weeks.

Abbreviations: HE, hematoxylin and eosin; NS, normal saline; SC, chitosan-modified selenium nanoparticles; SCD, DBAYL-conjugated, chitosan-modified selenium nanoparticles.

DBAYL and Ex-4. SC and BAY55-5837 only had slight or unobvious therapeutic effects.

After 12-week treatment with NS, SC, BAY55-9837, DBAYL, Ex-4 or SCD, the structural changes of pancreatic and adipose tissue in $\mathrm{db} / \mathrm{db}$ mice were examined with hematoxylin and eosin stain. As shown in Figure 8, in NS-treated $\mathrm{db} / \mathrm{db}$ mice, the distribution of pancreas cells was scattered and vacuolar degeneration was significant; furthermore, numerous exocrine acinar cells invaded pancreatic islets accompanied by infiltration of inflammatory cells, while the volume and number of adipose tissue cells were significantly increased compared with the normal $\mathrm{db} / \mathrm{m}$ mice (Figure $8 \mathrm{~A}$ and B). Conversely, in SCD-treated $\mathrm{db} / \mathrm{db}$ mice, the distribution and shape of the pancreatic islet cells were regular without vacuolar degeneration and inflammatory infiltration, and the size and shape of the adipocytes were small and basically uniform, which indicated pancreatic islet and adipose tissue structures tended to be normal (Figure 8A and B). Notably, SCD did not cause observable inflammatory and abnormal pathologic changes in pancreatic and adipose tissue in $\mathrm{db} / \mathrm{db}$ mice after intraperitoneal injection of SCD once per day for 12 weeks.

\section{Discussion}

T2D is a chronic metabolic disease, and its main pathogenesis is pancreatic islet beta cell dysfunction including the 
reduction in the cell number or functional decline, and insulin resistance. ${ }^{1}$ In medium- and long-term patients with $\mathrm{T} 2 \mathrm{D}$, the number of pancreatic islet beta cells significantly decreases, ${ }^{36}$ and insulin resistance induced by insulin sensitivity decline leads to the interference in glucose uptake and utilization. Current therapies for T2D mainly include insulin sensitizers, exogenous supply of insulin, $\alpha$-glucosidase inhibitors and sulfonylureas, but have limitations of therapeutic function and side effects caused by prolonged use, including the islet beta cell dysfunction or insulin signal transduction disorder. ${ }^{37}$ Therefore, a therapeutic consensus on protecting the beta cells efficiently, improving the insulin sensibility and drug combination has been recognized and accepted by more and more researchers.

Compared with antibodies and small molecule therapeutics, peptides possess lower size and higher specificity, respectively. Peptide-based drug development has shown a steady increase over the past years. ${ }^{38,39}$ Ex-4 (Exanatide) is a GLP1 derivative and is used for T2D treatment, but the risks of pancreatitis and common gastrointestinal side effects including vomiting or nausea were found in nearly $50 \%$ of the users, which limits its wide clinical applications. Several VPAC1/2 agonists such as BAY55-9837, Ro25-1392 and Ro25-1553 have been studied, and Ro25-1392 and Ro251553 can activate both VPAC1 and VPAC2 effectively. ${ }^{40,41}$ BAY55-9837 produced by chemical synthesis is a specific VPAC2 agonist and possesses glucose-dependent hypoglycemic and insulinotropic actions without gastrointestinal side effects. But the development of BAY55-9837 for T2D treatment has been hampered due to its in vivo limited bioavailability and short half-life. PEGylation, fusion expression of bioactive peptides and human serum albumin or Fc portion of an antibody, and combination therapy of peptide drugs and protease inhibitor have been explored to prolong the half-life and improve bioavailability. ${ }^{42-45}$ Although the fusion expression strategy may effectively extend the halflife of bioactive peptide, for maintaining high bioactivity, the bioactive peptides ought to be released in an orderly manner from the fusion protein or delivery carrier.

SCD consists of a highly selective VPAC2 agonist DBAYL with optimized structure based on the amino acid mutation of BAY55-9837 peptide and chitosan-modified SeNPs. DBAYL may promote effectively the proliferation of islet beta cells, insulin expression or secretion, insulin receptor expression, glucose uptake and utilization through selective activation of VPAC2 receptor. Chitosan-modified SeNP (SC) is both a drug delivery carrier and an auxiliary therapeutic agent because SC could not only slowly release the bioactive peptide DBAYL in an orderly manner through specific chymotrypsin and cathepsin D cleavage, but also significantly resist oxidative damage, moderately promote insulin receptor expression and slightly promote insulin secretion or glucose uptake. The high loading rate of $\mathrm{SC}$ can reduce SC dose, and a low dose of SeNPs may enhance the cell antioxidant activity and prevent islet beta cells apoptosis. ${ }^{22,23}$ Oxidative damage may be the important inducing factor during diabetes progression. ${ }^{46}$ In diabetic patients with persistent high blood glucose level, the body produces excessive ROS and reactive nitrogen; also, compared with other tissue cells, in the islet beta cells, the expression levels of superoxide dismutase, glutathione peroxidase and other antioxidases are low. Furthermore, the expression levels do not increase with increased oxidative stress levels. Also, the islet beta cells lack ROS clear proteins such as thioredoxin, which makes them more sensitive to ROS and reactive nitrogen. ${ }^{47}$ ROS can not only inhibit glucose-stimulated insulin secretion from pancreatic islet beta cells, but also obviously increase the cell cycle regulatory protein $\mathrm{p} 21$ expression, reduce insulin expression and diminish both mitochondrial and cytoplasmic calcium flux, causing oxidative damage and apoptosis of pancreatic islet beta cells. ${ }^{48,49}$

The in vitro results show that SeNPs, SC and SCD can all significantly reduce the ROS level in $\mathrm{H}_{2} \mathrm{O}_{2}$-injured INS-1 model cells mainly by SeNPs antioxygenation, and SCD can also obviously promote cell proliferation, insulin expression and secretion, glucose uptake and insulin receptor expression by DBAYL selectively activating VPAC2 receptor in INS-1 cells. Furthermore, SCD can slowly release DBAYL peptide in vitro; more importantly, the relatively rapid DBAYL release (about 63\%) from SCD during the first $12 \mathrm{~h}$ may provide enough DBAYL to execute its biological functions such as promoting postmeal insulin secretion. In agreement with this, in $\mathrm{db} / \mathrm{db}$ mice, the circulating half-life of SCD was about 169-, 7- and 3.5-fold longer than BAY55-9837, DBAYL and Ex-4, respectively, and the hypoglycemic activity of SCD (converting into the dosage of DBAYL and SC, they are $20 \mathrm{nmol} / \mathrm{kg}$ body weight and $42.1 \mu \mathrm{g} / \mathrm{kg}$ body weight, respectively) lasted for nearly $14 \mathrm{~h}$. These results indicated the structural defects from BAY55-9837 or DBAYL have been overcome, as characterized by long half-life, high bioavailability and long-lasting hypoglycemic activity. In IPGTT experiment, the SCD-treated $\mathrm{db} / \mathrm{db}$ mice displayed robust glucose-stimulated FPIS (5-15 min) and remarkably increased plasma insulin levels throughout IPGTT. Moreover, chronic administration of SCD also effectively improves fasting glucose levels, insulin resistance, lipid profiles, food or water 
consumption and body weight. Histopathologic study after chronic administration of SCD showed that in vivo, the novel SCD can also effectively improve the structure of pancreatic and adipose tissue; after all, the pancreatic islet disorder and the adipocyte volume increase are closely related with the indicators of the risk for developing T2D, systemic insulin resistance and dyslipidemia. ${ }^{50,51}$

\section{Conclusion}

In short, this study displays a novel peptide-conjugated, chitosan-modified SeNPs (SCD), consisting of a recombinant PACAP-derived peptide DBAYL capable of specifically activating VPAC2 receptor, and chitosan-modified SeNPs (SC) with slow release and therapeutic action. SCD displayed enhanced effects in improving insulin sensitivity, hyperglycemia and lipid profiles, but did not cause hypoglycemia, mainly through selectively activating VPAC2 receptor and resisting oxidative damage. Compared with Ex-4, a clinical drug needed to be injected twice per day, SCD has the potential to become a long-acting anti-T2D therapeutic owing to the synergy effects of SC and DBAYL.

\section{Acknowledgments}

This work was supported by grants from the National Natural Science Foundation of China (No 81373314, 81473688), the Natural Science Foundation of Guangdong Province, China (No 2015A030313333), the Science and Technology Planning Project of Guangdong Province, China (No 2014A020210015, 2013B090500105 and 2014A020212672), Guangzhou Municipal Science and Technology Program (No 201707010245), the Fundamental Research Funds for the Central Universities (No 21615412 and 21615464), Guangzhou Municipal Enterprise Research and Development Institutions Construction Project (No 201503010064) and the Cooperation Ombudsman Workstation Project in Industry, Education and Research of Guangdong Province, China (No 2013B090900010).

\section{Disclosure}

The authors report no conflicts of interest in this work.

\section{References}

1. Winzell MS, Ahren B. Role of VIP and PACAP in islet function. Peptides. 2007;28(9):1805-1813.

2. Ghzili H, Grumolato L, Thouennon E, et al. Role of PACAP in the physiology and pathology of the sympathoadrenal system. Front Neuroendocrinol. 2008;29(1):128-141.

3. Vaudry D, Falluel-Morel A, Bourgault S, et al. Pituitary adenylate cyclase-activating polypeptide and its receptors: 20 years after the discovery. Pharmacol Rev. 2009;61(3):283-357.
4. Gray SL, Cummings KJ, Jirik FR, Sherwood NM. Targeted disruption of the pituitary adenylate cyclase-activating polypeptide gene results in early postnatal death associated with dysfunction of lipid and carbohydrate metabolism. Mol Endocrinol. 2001;15(10):1739-1747.

5. Nakata M, Kohno D, Shintani N, et al. PACAP deficient mice display reduced carbohydrate intake and PACAP activates NPY-containing neurons in the rat hypothalamic arcuate nucleus. Neurosci Lett. 2004; 370(2-3):252-256.

6. Tomimoto S, Ojika T, Shintani N, et al. Markedly reduced white adipose tissue and increased insulin sensitivity in adcyap1-deficient mice. J Pharmacol Sci. 2008;107(1):41-48.

7. Yamamoto K, Hashimoto H, Tomimoto S, et al. Overexpression of PACAP in transgenic mouse pancreatic beta-cells enhances insulin secretion and ameliorates streptozotocin-induced diabetes. Diabetes. 2003;52(5):1155-1162.

8. Asnicar MA, Koster A, Heiman ML, et al. Vasoactive intestinal polypeptide/pituitary adenylate cyclase-activating peptide receptor 2 deficiency in mice results in growth retardation and increased basal metabolic rate. Endocrinology. 2002;143(10):3994-4006.

9. Tsutsumi M, Claus TH, Liang Y, et al. A potent and highly selective VPAC2 agonist enhances glucose-induced insulin release and glucose disposal: a potential therapy for type 2 diabetes. Diabetes. 2002;51(5): 1453-1460.

10. Green BD, Irwin N, Flatt PR. Direct and indirect effects of obestatin peptides on food intake and the regulation of glucose homeostasis and insulin secretion in mice. Peptides. 2007;28(5):981-987.

11. Yada T, Sakurada M, Filipsson K, Kikuchi M, Ahren B. Intraperitoneal PACAP administration decreases blood glucose in GK rats, and in normal and high fat diet mice. Ann N Y Acad Sci. 2000;921:259-263.

12. Ma Y, Luo T, Xu W, Ye Z, Hong A. A new recombinant pituitary adenylate cyclase-activating peptide-derived peptide efficiently promotes glucose uptake and glucose-dependent insulin secretion. Acta Biochim Biophys Sin (Shanghai). 2012;44(11):948-956.

13. Pan CQ, Li F, Tom I, et al. Engineering novel VPAC2-selective agonists with improved stability and glucose-lowering activity in vivo. J Pharmacol Exp Ther. 2007;320(2):900-906.

14. Sakurai Y, Shintani N, Hayata A, Hashimoto H, Baba A. Trophic effects of PACAP on pancreatic islets: a mini-review. J Mol Neurosci. 2011; 43(1):3-7.

15. Yung SL, Dela Cruz F, Hamren S, et al. Generation of highly selective VPAC2 receptor agonists by high throughput mutagenesis of vasoactive intestinal peptide and pituitary adenylate cyclase-activating peptide. J Biol Chem. 2003;278(12):10273-10281.

16. Hamelink C, Tjurmina O, Damadzic R, et al. Pituitary adenylate cyclaseactivating polypeptide is a sympathoadrenal neurotransmitter involved in catecholamine regulation and glucohomeostasis. Proc Natl Acad Sci US A. 2002;99(1):461-466.

17. McGregor DP. Discovering and improving novel peptide therapeutics. Curr Opin Pharmacol. 2008;8(5):616-619.

18. Malik DK, Baboota S, Ahuja A, Hasan S, Ali J. Recent advances in protein and peptide drug delivery systems. Curr Drug Deliv. 2007; 4(2): 141-151.

19. Pawar R, Ben-Ari A, Domb AJ. Protein and peptide parenteral controlled delivery. Expert Opin Biol Ther. 2004;4(8):1203-1212.

20. Zhang JS, Gao XY, Zhang LD, Bao YP. Biological effects of a nano red elemental selenium. Biofactors. 2001;15(1):27-38.

21. Combs GF, Jr, Gray WP. Chemopreventive agents: selenium. Pharmacol Ther. 1998;79(3):179-192.

22. Rayman MP. The importance of selenium to human health. Lancet. 2000;356(9225):233-241.

23. Kumar GS, Kulkarni A, Khurana A, Kaur J, Tikoo K. Selenium nanoparticles nvolve HSP-70 and SIRT1 in preventing the progression of type 1 diabetic nephropathy. Chem Biol Interact. 2014;223:125-133.

24. Liu W, Li X, Wong YS, et al. Selenium nanoparticles as a carrier of 5-fluorouracil to achieve anticancer synergism. ACS Nano. 2012;6(8): 6578-6591. 
25. Rao L, Ma Y, Zhuang M, Luo T, Wang Y, Hong A. Chitosan-decorated selenium nanoparticles as protein carriers to improve the in vivo half-life of the peptide therapeutic BAY 55-9837 for type 2 diabetes mellitus. Int J Nanomedicine. 2014;9:4819-4828.

26. Ma Y, Zhao S, Wang X, et al. A new recombinant PACAP-derived peptide efficiently promotes corneal wound repairing and lacrimal secretion. Invest Ophthalmol Vis Sci. 2015;56(8):4336-4349.

27. Nishimoto M, Furuta A, Aoki S, Kudo Y, Miyakawa H, Wada K. $\mathrm{PACAP} / \mathrm{PAC} 1$ autocrine system promotes proliferation and astrogenesis in neural progenitor cells. Glia. 2007;55(3):317-327.

28. Dennis MS, Zhang M, Meng YG, et al. Albumin binding as a general strategy for improving the pharmacokinetics of proteins. J Biol Chem. 2002;277(38):35035-35043.

29. Ma Y, Ma M, Dai Y, Hong A. Expression, identification and biological effects of a novel VPAC2-specific agonist with high stability and bioactivity. Acta Biochim Biophys Sin (Shanghai). 2010;42(1):21-29.

30. Lyu GM, Wang YJ, Huang X, et al. Hydrophilic CeO2 nanocubes protect pancreatic beta-cell line INS-1 from H2O2-induced oxidative stress. Nanoscale. 2016;8(15):7923-7932.

31. Annesley SJ, Lay ST, De Piazza SW, et al. Immortalized Parkinson's disease lymphocytes have enhanced mitochondrial respiratory activity. Dis Model Mech. 2016;9(11):1295-1305.

32. Ma Y, Fang S, Zhao S, et al. A recombinant slow-release PACAPderived peptide alleviates diabetes by promoting both insulin secretion and actions. Biomaterials. 2015;51:80-90.

33. Conti R, Mannucci E, Pessotto P, et al. Selective reversible inhibition of liver carnitine palmitoyl-transferase 1 by teglicar reduces gluconeogenesis and improves glucose homeostasis. Diabetes. 2011;60(2): 644-651.

34. Wang WY, Zhang ZJ, Wang J, Wang HW. An experimental study on the effects of curcumin on posterior capsule opacification in young rabbit eyes. Chin Med J (Engl). 2011;124(21):3527-3531.

35. Yu B, Zhang Y, Zheng W, Fan C, Chen T. Positive surface charge enhances selective cellular uptake and anticancer efficacy of selenium nanoparticles. Inorg Chem. 2012;51(16):8956-8963.

36. Butler AE, Janson J, Bonner-Weir S, Ritzel R, Rizza RA, Butler PC. Beta-cell deficit and increased beta-cell apoptosis in humans with type 2 diabetes. Diabetes. 2003;52(1):102-110.

37. Moller DE. New drug targets for type 2 diabetes and the metabolic syndrome. Nature. 2001;414(6865):821-827.

38. Marx V. Watching peptide drugs grow up. Chem Eng News Arch. 2005; 83(11):17-24

39. Sato AK, Viswanathan M, Kent RB, Wood CR. Therapeutic peptides: technological advances driving peptides into development. Curr Opin Biotechnol. 2006;17(6):638-642.
40. Gourlet P, De Neef P, Cnudde J, Waelbroeck M, Robberecht P. In vitro properties of a high affinity selective antagonist of the VIP1 receptor. Peptides. 1997;18(10):1555-1560.

41. Xia M, Sreedharan SP, Bolin DR, Gaufo GO, Goetzl EJ. Novel cyclic peptide agonist of high potency and selectivity for the type II vasoactive intestinal peptide receptor. J Pharmacol Exp Ther. 1997;281(2): 629-633.

42. Picha KM, Cunningham MR, Drucker DJ, et al. Protein engineering strategies for sustained glucagon-like peptide-1 receptor-dependent control of glucose homeostasis. Diabetes. 2008;57(7):1926-1934.

43. Stork R, Muller D, Kontermann RE. A novel tri-functional antibody fusion protein with improved pharmacokinetic properties generated by fusing a bispecific single-chain diabody with an albuminbinding domain from streptococcal protein G. Protein Eng Des Sel. 2007;20(11):569-576.

44. Muller D, Karle A, Meissburger B, Hofig I, Stork R, Kontermann RE. Improved pharmacokinetics of recombinant bispecific antibody molecules by fusion to human serum albumin. J Biol Chem. 2007;282(17): 12650-12660.

45. Maianti JP, McFedries A, Foda ZH, et al. Anti-diabetic activity of insulin-degrading enzyme inhibitors mediated by multiple hormones. Nature. 2014;511(7507):94-98.

46. Rosen P, Nawroth PP, King G, Moller W, Tritschler HJ, Packer L. The role of oxidative stress in the onset and progression of diabetes and its complications: a summary of a congress series sponsored by UNESCOMCBN, the American Diabetes Association and the German Diabetes Society. Diabetes Metab Res Rev. 2001;17(3):189-212.

47. Tiedge M, Lortz S, Drinkgern J, Lenzen S. Relation between antioxidant enzyme gene expression and antioxidative defense status of insulinproducing cells. Diabetes. 1997;46(11):1733-1742.

48. Maechler P, Jornot L, Wollheim CB. Hydrogen peroxide alters mitochondrial activation and insulin secretion in pancreatic beta cells. $J$ Biol Chem. 1999;274(39):27905-27913.

49. Kaneto H, Kajimoto Y, Fujitani Y, et al. Oxidative stress induces p21 expression in pancreatic islet cells: possible implication in beta-cell dysfunction. Diabetologia. 1999;42(9):1093-1097.

50. Weyer C, Foley JE, Bogardus C, Tataranni PA, Pratley RE. Enlarged subcutaneous abdominal adipocyte size, but not obesity itself, predicts type II diabetes independent of insulin resistance. Diabetologia. 2000; 43(12):1498-1506.

51. Kilimnik G, Zhao B, Jo J, et al. Altered islet composition and disproportionate loss of large islets in patients with type 2 diabetes. PLoS One. 2011;6(11):e27445.
International Journal of Nanomedicine

\section{Publish your work in this journal}

The International Journal of Nanomedicine is an international, peerreviewed journal focusing on the application of nanotechnology in diagnostics, therapeutics, and drug delivery systems throughout the biomedical field. This journal is indexed on PubMed Central, MedLine, CAS, SciSearch ${ }^{\circledR}$, Current Contents ${ }^{\circledR} /$ Clinical Medicine,

\section{Dovepress}

Journal Citation Reports/Science Edition, EMBase, Scopus and the Elsevier Bibliographic databases. The manuscript management system is completely online and includes a very quick and fair peer-review system, which is all easy to use. Visit http://www.dovepress.com/ testimonials.php to read real quotes from published authors. 